\title{
Interplay between fracturing and hydrothermal fluid flow in the asón valley hydrothermal dolomites (Basque- Cantabrian Basin, Spain)
} DOI:

10.1144/SP370.10

Link to publication record in Manchester Research Explorer

Citation for published version (APA):

Iriarte, E., A. López-Horgue, M., Schroeder, S., \& Caline, B. (2012). Interplay between fracturing and hydrothermal fluid flow in the asón valley hydrothermal dolomites (Basque-Cantabrian Basin, Spain). In Geological Society Special Publication/Geol. Soc. Spec. Publ. (Vol. 370, pp. 207-227). (Geological Society, London, Special Publications). Geological Society . https://doi.org/10.1144/SP370.10

Published in:

Geological Society Special Publication|Geol. Soc. Spec. Publ.

\section{Citing this paper}

Please note that where the full-text provided on Manchester Research Explorer is the Author Accepted Manuscript or Proof version this may differ from the final Published version. If citing, it is advised that you check and use the publisher's definitive version.

\section{General rights}

Copyright and moral rights for the publications made accessible in the Research Explorer are retained by the authors and/or other copyright owners and it is a condition of accessing publications that users recognise and abide by the legal requirements associated with these rights.

\section{Takedown policy}

If you believe that this document breaches copyright please refer to the University of Manchester's Takedown Procedures [http://man.ac.uk/04Y6Bo] or contact uml.scholarlycommunications@manchester.ac.uk providing relevant details, so we can investigate your claim.

\section{OPEN ACCESS}


Geological Society, London, Special Publications Online First

\title{
Interplay between fracturing and hydrothermal fluid flow in the Asón Valley hydrothermal dolomites (Basque-Cantabrian Basin, Spain)
}

\author{
E. Iriarte, M. A. López-Horgue, S. Schroeder and B. Caline
}

Geological Society, London, Special Publications v.370, first published September 5, 2012; doi 10.1144/SP370.10

\section{Email alerting service}

Permission request

Subscribe

How to cite click here to receive free e-mail alerts when new articles cite this article

click here to seek permission to re-use all or part of this article

click here to subscribe to Geological Society, London, Special Publications or the Lyell Collection

click here for further information about Online First and how to cite articles

\section{Notes}




\title{
Interplay between fracturing and hydrothermal fluid flow in the Asón Valley hydrothermal dolomites (Basque-Cantabrian Basin, Spain)
}

\author{
E. IRIARTE ${ }^{1 *}$, M. A. LÓPEZ-HORGUE ${ }^{2}$, S. SCHROEDER ${ }^{3} \&$ B. CALINE ${ }^{3}$ \\ ${ }^{1}$ Departamento Ciencias Históricas y Geografía, Laboratorio de Evolución Humana, \\ Universidad de Burgos, Plaza de Misael Bañuelos s/n, Edificio I +D i, 09001, Burgos, Spain \\ ${ }^{2}$ Estratigrafia eta Paleontologia, Zientzia eta Teknologia Fakultatea, UPV/EHU University \\ of the Basque Country, Sarriena z/g, 48940 Leioa, Basque Country, Spain \\ ${ }^{3}$ Total Exploration \& Production, Carbonate Sedimentology Group CSTJF, \\ Avenue Larribau, 64018 Pau Cedex, France
}

*Corresponding author (e-mail: eiriarte@ubu.es)

\begin{abstract}
In Asón Valley hydrothermal dolomite area (Basque-Cantabrian Basin, northern Spain), an overlapping stepover area between two major basement faults, the Cabuerniga and Ruahermosa transtensional faults, was the location for different scales and types of extensive fractures. This fracture mesh affected the Albian Ranero limestone and was formed in a dilational jog, a regional fluid throughflow area. It acted as pathway for overpressured fluids that controlled the dolomite mineralization in the Ranero massif area. The study of synchronous structural features, fluid flow channelling and dolomitization processes indicated their tectonic control. The fluid circulated and concentrated preferentially in more fractured areas with increased permeability, such as extensional chimneys, creating dolomite bodies. Repeated extensive tectonic activity enhanced fracture porosity, promoting overpressured fluid migration and cyclical dolomitization events. The studied fracture pattern suggests the presence of sinistral transtension during the formation of extensional joint-sets that channellized the mineralizing fluid-flow. A gradation in structural features and dolomite facies and textures is visible from the main Pozalagua fault dolomite body to peripheral dolomite bodies as the Breccia body and Ranero megajoints. These differences could reflect a proximal-distal trend from the main fluid-flow area along the Pozalagua fault to the Ranero megajoints.
\end{abstract}

The knowledge of the three-dimensional geometry and spatial organization of structural traps has been a powerful tool in hydrocarbon exploration for many years. Nevertheless, the applied models of structure geometry and organization do not usually consider the interaction of fluids and structures during deformation when the structure is being initiated and amplified. However, advances in the understanding of the role of fluid pressure in faults and fractures and the subsequent influence of these anisotropies on the fluid migration opened a new chapter in the role of structural geology in reservoir development. Particularly in relation to the genesis of hydrothermal mineral deposits (Sibson et al. 1975, 1988; Sibson 1990; Cosgrove 1995, 1998; Coward et al. 1998; Connolly \& Cosgrove 1999; Aydin 2000; Graham et al. 2006), it is now accepted that not only do fluids facilitate deformation but that the reverse is also true, that is, that fracturing can provide pathways for fluid migration.

Hydrothermal dolomites (HTD) have been major productive reservoirs, with well-documented Palaeozoic and some Mesozoic examples, but their outcrop analogues still remain poorly studied (e.g. Davies \& Smith 2006). The main HTD reservoirs are known from North America and the Middle East (e.g. Ordovician Trenton-Black River Group, Smith 2006; Middle Devonian of British Columbia, Lonnee \& Machel 2006; Khuff Formation, Sudrie et al. 2006; Ghawar oilfield, Cantrell et al. 2001). By contrast, there are only few outcrops of HTD that can serve to better understand the controlling factors on hydrothermal dolomitization and the poroperm variations (e.g. Al-Aasm, 2003; Gasparrini et al. 2003; López-Horgue et al. 2005, 2010; Nader et al. 2007; Schröder et al. 2008; Sharp et al. 2010; Lapponi et al. 2011; Ronchi et al. 2012). Most of the known HTD occurrences have an important structural control; extensional and/or strike-slip settings are particularly common geodynamical settings (e.g. Davies \& Smith 2006) and hence the need to understand the role of faulting and fracturing in enhancing rock permeability becomes paramount.

The hydrothermal dolomite bodies outcropping in the Asón Valley (Basque-Cantabrian Basin, 
northern Spain; López-Horgue et al. 2010; Shah et al. 2010) are regarded as an outstanding outcrop analogue of HTD. These contribute to the role of tectonic deformation and fluid flow controlled by faults and fractures and the subsequent influence of these structures on the migration and channelling of dolomitizing fluids (Iriarte et al. 2011). This study of the Albian Ramales platform limestone host-rock and the fracture-related hydrothermal dolomitization has enabled characterization of the role of tectonic deformation and fluid flow in the formation of a connected fracture mesh that controlled the distribution of HTD.

\section{The Asón Valley HTD}

Outcrops of HTD formed in the Cretaceous Ramales platform limestones in the Asón Valley (western Basque-Cantabrian Basin) have provided key examples to understand the interplay between fracturing and mineralizing fluid flow and their role in hydrothermal dolomitization processes (López-Horgue et al. 2010, 2011a; Fig. 1). The HTD bodies are embedded in Albian Ramales carbonate platform limestones (López-Horgue 2000). The Ramales carbonate platform originated on a low subsiding tectonic block of the western margin of the Basque-Cantabrian Basin (BCB), facing a deeper subsiding Karrantza basin to the SE (Figs 1 \& 2) and the Bilbao basin to the north. The origin of the tectonic compartmentalization was related to differential subsidence because of the intense transtensional activity in the $\mathrm{BCB}$ owing to the Iberian plate drift during the opening of the Bay of Biscay (Srivastava 1990; García-Mondéjar et al. 1996; Olivet 1996; García-Mondéjar et al. 2004a, $b, 2005)$.

In the Ranero massif area several HTD bodies crosscut the Ramales platform limestones along fault and fracture sets of different size. HTD bodies crosscut the platform margin extending from slope to inner platform settings and show a vertical development of more than $500 \mathrm{~m}$ in the most important HTD bodies (Fig. 2). Kilometre-scale branches expand following the stratification in platform interior carbonates. Dolomitization is usually pervasive and independent of the limestone facies (López-Horgue et al. 2010; Shah et al. 2010), and main dolomite facies are fine replacive, sucrosic and coarse crystalline saddle dolomites (using the classification of Sibley \& Gregg 1987). The accommodation of major extensional to transtensional tectonic activity in the Ranero massif area during the Albian to Turonian created a stepover between

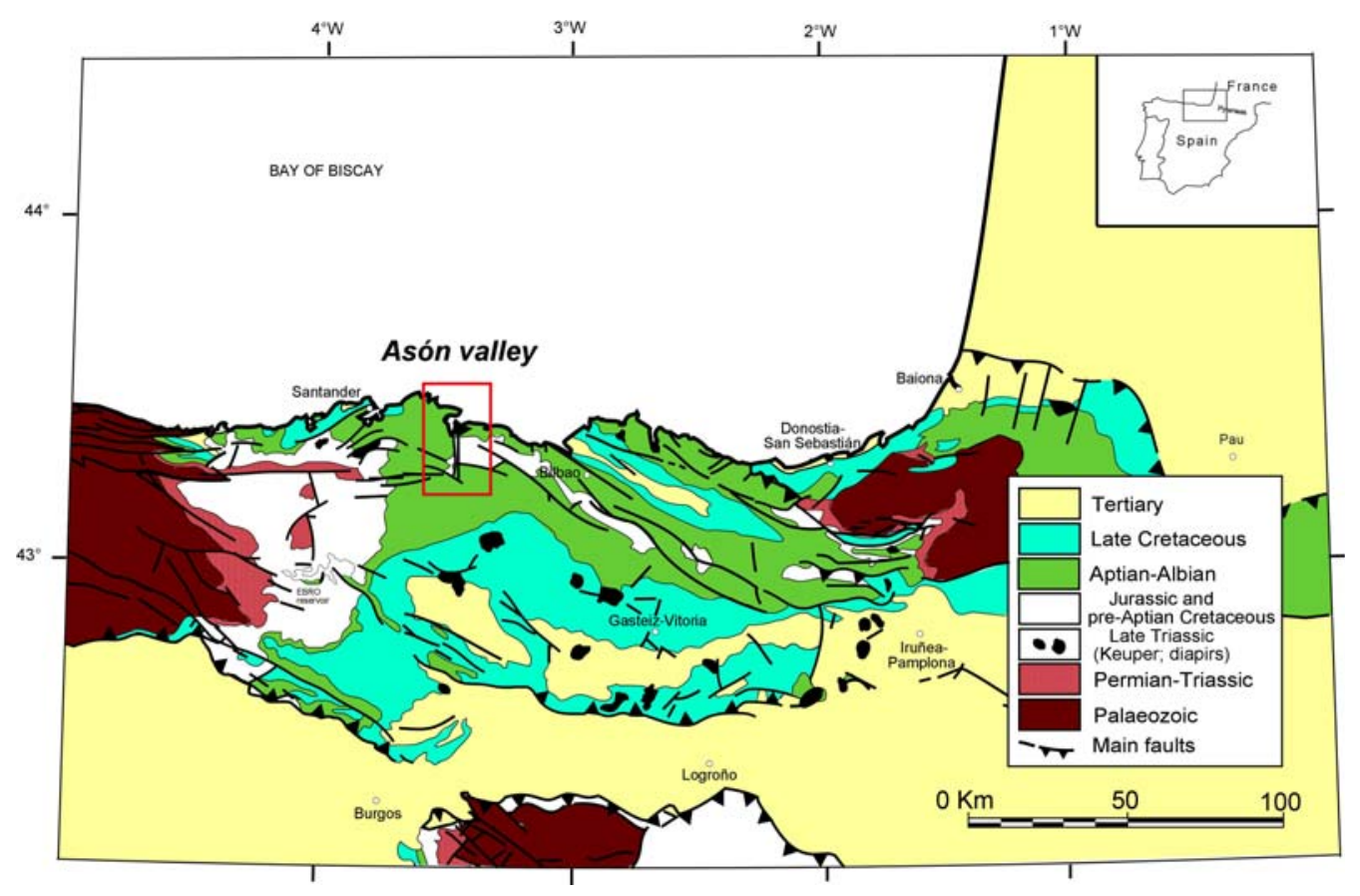

Fig. 1. Simplified geological map of the Basque Cantabrian Basin. The study area, the Ranero massif, lies within the boxed Asón valley area. 


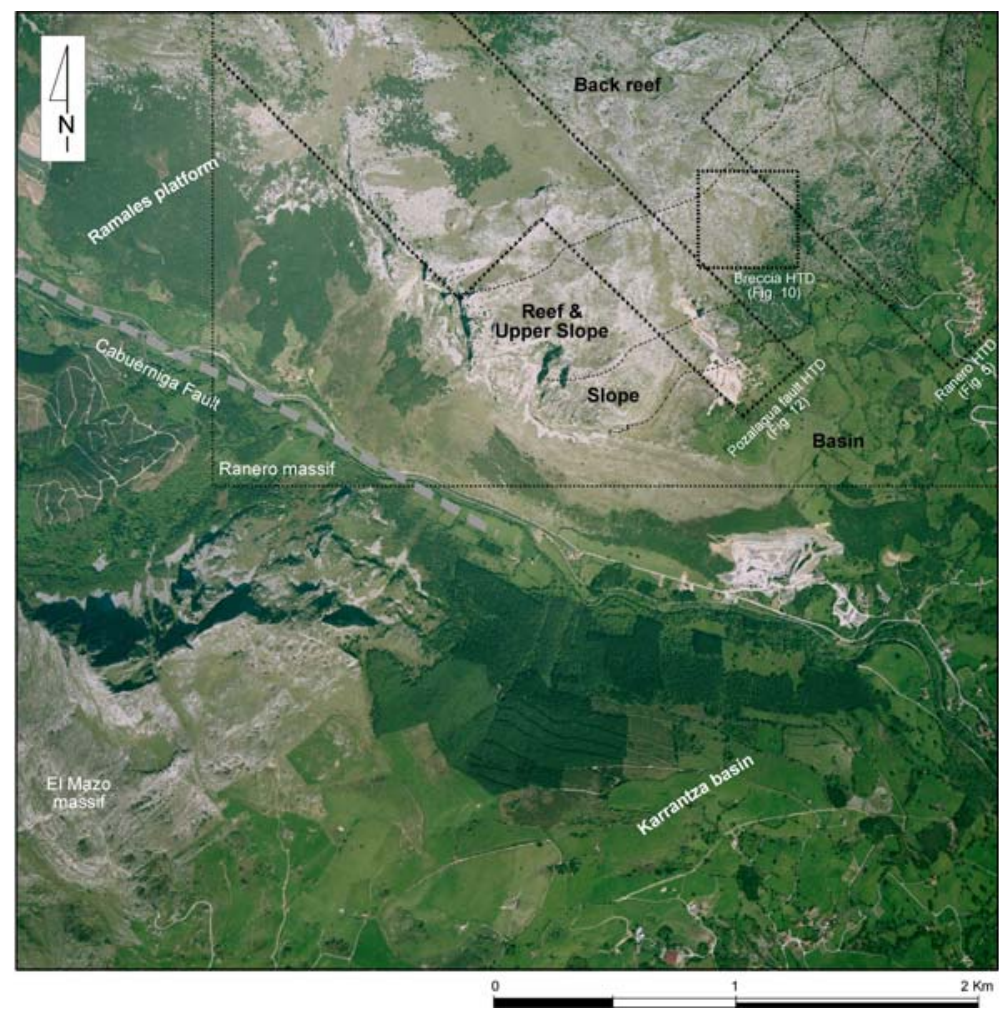

Fig. 2. Aerial photograph of the Ranero massif area. The hydrothermal dolomites (HTD) bodies mentioned in the text are boxed. Note the transition from Ramales carbonate platform to the Karrantza basin area to the SE. The Cabuérniga fault extends NW-SE along the Karrantza river Valley (parallel to the main road in the valley bottom).

west-east trending Cabuérniga and Ruahermosa main basement faults bounded to the west by the north-south trending Ramales fault (Fig. 3). In this setting, fluids and diapiric Keuper claystones containing dolerite bodies (possible Mg sources) ascended from more subsiding basinal areas through major fault zones deforming (folding and fracturing) and dolomitizing Ramales platform limestone units (López-Horgue et al. 2010). Petrography, C, O and $\mathrm{Sr}$ isotope-data and fluid inclusion analysis support polyphase hydrothermal dolomitization at fluid-temperatures between 75 and $240{ }^{\circ} \mathrm{C}$ and highly variable salinities of up to 22 wt\% $\mathrm{NaCl}$ (López-Horgue et al. 2010).

\section{Structural controls in fluid flow}

The Ranero massif is mainly composed of Aptian and Albian limestones of the Ramales shallow marine carbonate platform (López-Horgue 2000). It comprises inner platform and platform margin settings of the Ramales platform and is limited by two main Cretaceous transtensional basement faults, the Cabuérniga and Ruahermosa faults (Figs 2 \& 3).

\section{Regional-scale structure: the Ranero stepover}

The Cabuérniga and Ruhaermosa faults form a stepover in the present-day Ranero massif area (Fig. 4). This structural disposition created a densely fractured transtensional zone, a dilational jog, crosscut by different scale fractures and faults (e.g. Pozalagua Fault). These created an interconnected network of fractures that controlled the presence of HTD mineralization along the limestone units of the Ramales platform (Figs 3 \& 4; López-Horgue et al. 2010). The main HTD bodies in the Ranero stepover are related to transtensional faults, such as the Pozalagua fault, and to different scale joint-sets (Fig. 4a) located in the intra-jog fluid throughflow and concentration areas in agreement with proposed theoretical models (Aydin \& Nur 1985; Connolly \& Cosgrove 1999; Fig. 4b, c). Additionally, along the Ruahermosa fault trace, in the northern edge of the Ranero stepover, an 


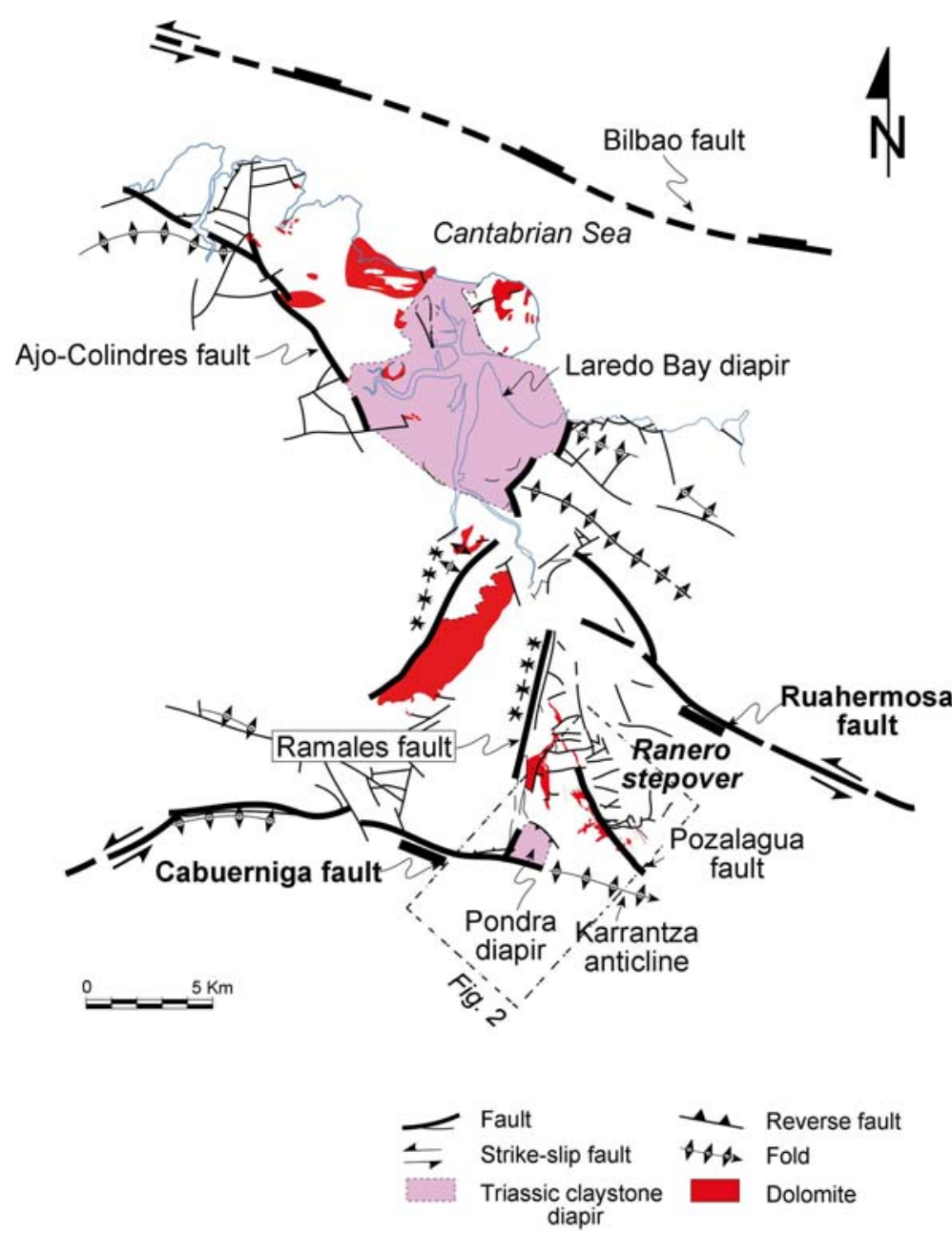

Fig. 3. Structural map of the Asón Valley. The main structural features from the Ranero massif area are indicated. Note the Ranero stepover between the sinistral Cabuérniga and Ruahermosa basement faults. Red areas correspond to main Asón Valley HTD bodies and pink areas to diapirs. The location of Figure 2 is shown within a black box.

important Late Albian hydrothermal calcite mineralization is also present (Simón et al. 1999; Aranburu et al. 2002) coinciding with another typical fluid throughflow area in stepover areas (cf. Connolly \& Cosgrove 1999; Fig. 4b).

\section{Local-scale structure: joints, megajoints and faults}

The Albian host limestone in Ranero massif is a rimmed platform that shows four differentiated facies-belts: backreef, reef margin, slope and basinal facies (López-Horgue 2000; Fig. 2). The platform margin is of NE-SW orientation and shows sedimentary geometries and facies exceptionally well preserved and exposed in the Ranero area.

Detailed mapping of the Ranero intra-jog area has permitted the identification of dolomite bodies at different scales (Figs $2 \& 4$ ). Their size varies from small dolomite-filled millimetric joints to decimetric pockets and kilometre-scale large bodies. Four main dolomite bodies have been differentiated from east to west (Fig. 2): the two Ranero megajoints (Ranero West and Ranero Eeast), the Breccia dolomite body and the Pozalagua fault dolomite body.

Dolomite bodies crosscut the above-mentioned platform margin vertically, perpendicular to bedding. Their boundaries are sharp and usually demarked by well-developed fracture sets that affect 
(a)

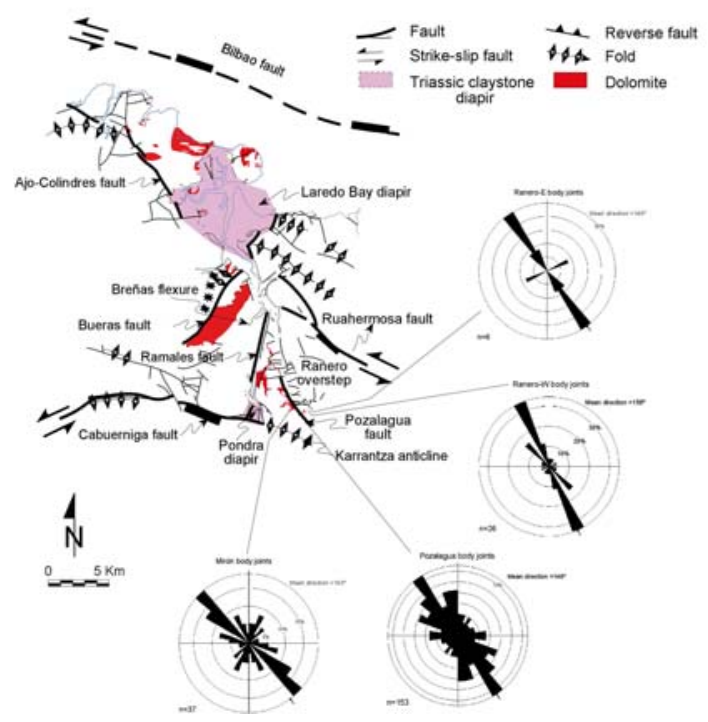

(b)

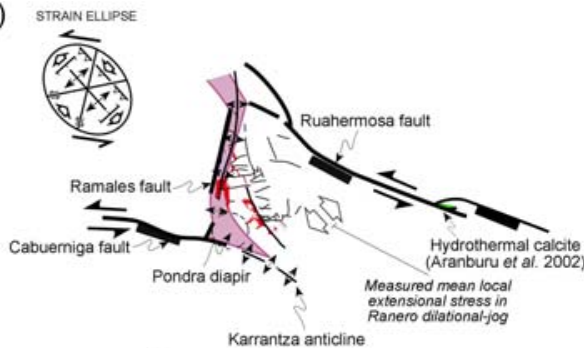

(c)

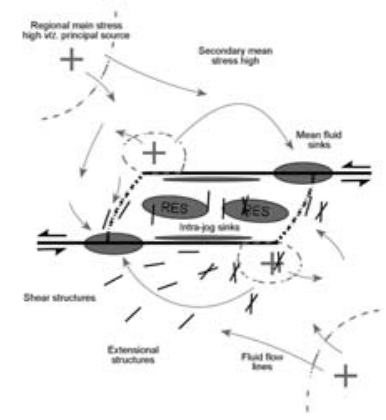

Fig. 4. Ranero massif stepover. (a, b) Structural sketch of the Ranero massif stepover. The measured directions of dolomite-filled joints are shown (modified from López-Horgue et al. 2010). (c) Summary diagram illustrating the fluid flow within and around a statically loaded dilational jog. The principal reservoirs predicted are the intra-jog areas (RES), that is, Pozalagua and Ranero bodies in the studied area. Minor fluid accumulation may occur between the regional and secondary extra-jog mean stress-highs. Sites of probable mineralization coincide with regions of high fluid throughflow (after Connolly \& Cosgrove 1999).

both the host limestone and the dolomites. The shape of dolomite bodies varies from very elongate and relatively thin morphologies (i.e. the Ranero megajoints) to more irregular and branched geometries (i.e. the Breccia and Pozalagua fault bodies).

The dolomite facies and textures observed in the dolomite bodies are highly variable. They reflect multiple phases of brecciation/dolomitization. All dolomite bodies are densely crosscut by two main sets of joints, with the jointing more dense in the dolomite bodies than in the host limestone. The joints tend to connect and form fracture meshes and are commonly filled by dolomite and/or calcite cements, suggesting the existence of deformation phases related to subsequent mineralizing fluid flow events. The Pozalagua and Breccia bodies are good examples of limestone breccias of hydraulic origin (López-Horgue et al. 2010, 2011a). Original vuggy porosity in dolomite is now partially or totally occluded by calcite cements that were able to form decametre scale veins within the dolomite bodies.

All of the features mentioned above point to fracture-related dolomitization. However, the different characteristics observed in dolomite bodies from Ranero area permit us to further differentiate these processes.

\section{Ranero megajoints}

The Ranero dolomite bodies are situated in the eastern part of the study area, to the NW of the Ranero village (Figs 2 \& 5). The Ranero Megajoint dolomite bodies are relatively thin (metre scale) and parallel to the main joint-set $\left(S_{1}\right)$ observed in the study area (Fig. 6). The host limestone is composed of micritic slope and reefal limestones and marly and calcarenite basinal sediments (Figs 2 \& 5). They are neighbouring hectometre-scale elongated dolomite bodies that pinch out and bifurcate at their upper and lower ends.

Ranero West is the western dolomite body; it is shorter and thinner than its eastern counterpart (Fig. 5). It is $450 \mathrm{~m}$ long in a NW-SE direction and $1-5 \mathrm{~m}$ wide. Its boundaries are planar and steeply dipping $\left(70^{\circ}\right)$ surfaces parallel to the main $S_{1}$ joint-set (Fig. 6). The jointing in the host limestone increases in density towards the dolomite body margins (Fig. 7a, b). Locally, smaller rectilinear dolomite bodies diverge and converge from the main body.

Dolomite facies in both the megajoints consists mainly of fine replacive anhedral dolomite, where locally bioclast-ghosts have been observed in thin section (López-Horgue et al. 2010). There are 


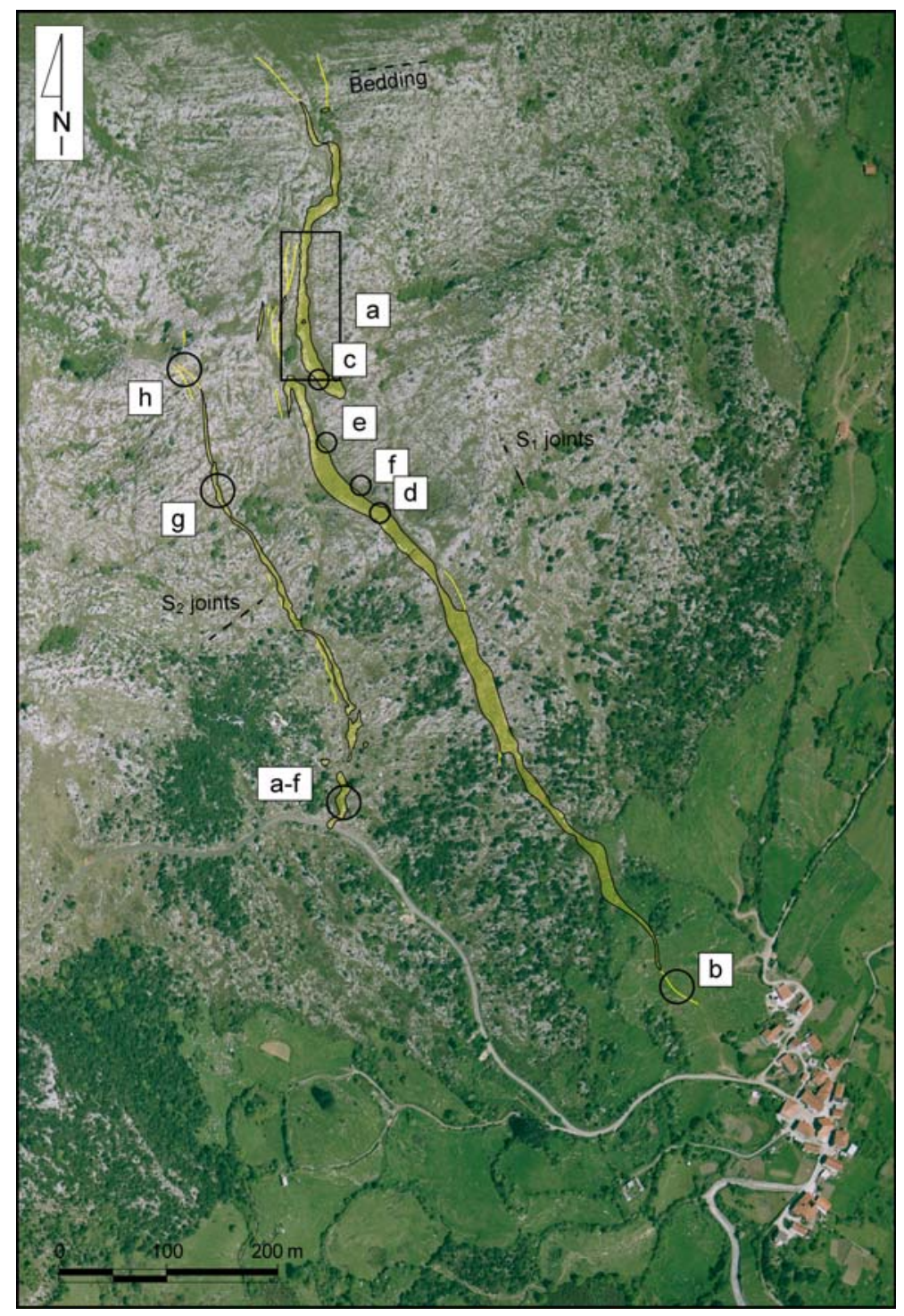

Fig. 5. Aerial photograph and detailed cartography of Ranero HTD megajoints and location of the photographs showed in the Figures 7 and $8(\mathrm{a}-\mathrm{h})$.

many planar discontinuities attributed to $S_{1}$ and $S_{2}$ extensional joint-sets; intercristallyne porosity is common and vuggy porosity is scarce (Fig. 7c-g). Calcite forms decimetric veins and smaller veinlets within the dolomite mass (Fig. $7 \mathrm{~d}-\mathrm{g}$ ). The dolomite/calcite ratio increases towards the upper (NW) and lower (SE) ends of the body, where only calcite crystals are present cementing the vein (Fig. $7 g, h$ ). The calcite veins intrude the dolomite body through extensional joints (preferentially $S_{1}$ ) and even brecciate the dolomite (calcite-cemented mosaic to rubble dolomite floatbreccias), post-dating the dolomitization (Fig. 7d, f, g).

Ranero East dolomite body is $990 \mathrm{~m}$ long in a NW-SE orientation and its maximum width is $25 \mathrm{~m}$ (Figs $5 \& 8$ ). It has practically the same characteristics as Ranero West, but in this dolomite body the $S_{1}$ joint-set is much more pervasive and sometimes the only joint-set that could be recognized within the dolomite (Fig. 8c, d). The massive fine replacive dolomite is predominant. Locally 'protozebra' lamination is visible and 

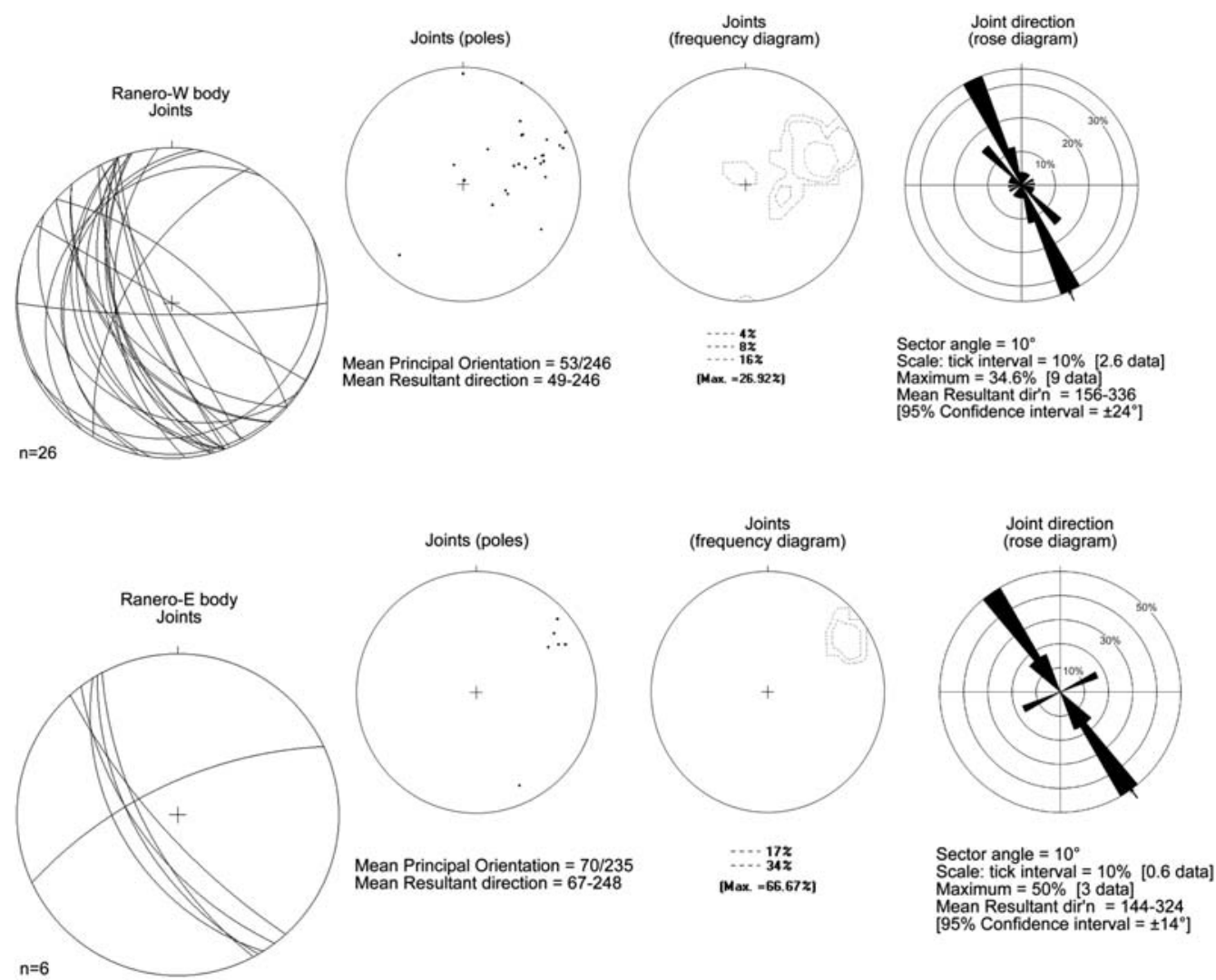

Fig. 6. Stereograms and rose diagram of joint measurements in Ranero East and Ranero West HTD megajoints.

formed by millimetre-size vuggy porosity, partially filled with saddle dolomite crystals, aligned parallel to the predominant joint-set $\left(S_{1}\right)$ (Fig. 8d). Latestage calcite veins form along $S_{1}$ joints and less frequently through $S_{2}$, joints and cement dolomite breccias in the dolomite body.

Small-scale joints measured next to the boundaries of the Ranero bodies show that they were not simple extensional fractures (Fig. 9). A sinistral shear component and vertical movement could be deduced from the study of small-scale en echelon joints developed in the fringe of major Ranero megajoints (Fig. 9). These fringe-joints are usually set at an angle of $5-25^{\circ}$ to the main joint face and they develop usually when the main joint is a shear fracture (Neville 1968).

\section{Breccia dolomite body}

The Breccia dolomite body is located to the west of Ranero bodies. It is $270 \mathrm{~m}$ long in a NW-SE direction and 100-270 $\mathrm{m}$ wide (Figs 2 \& 10). Although it is mainly elongated parallel to $S_{1}$ direction, it has a few lateral branches that make its width highly variable (Figs $10 \& 11$ ). The contact with the host limestone is transitional from densely jointed limestone to cement supported breccia in the lower part (SE) of the body (Fig. 11a, c). The upper (NW) part of the breccia body consists of replacive dolomite with sharp contacts (fracture limited) with the host limestone (Fig. 11b, b'). Both the host limestone (slope clinoforms of marly and micritic limestone) and the dolomite body are affected by two main joint-sets, the steeply northeastward-dipping $S_{1}$ set and the gently dipping $S_{2}$ (Figs $10 \& 11 \mathrm{~b}^{\prime}$, d, e). The upper (NW) and lower $(S)$ ends of the body are planar and parallel to $S_{2}$ joint-set, which probably controlled these boundaries (Fig. 11b, e).

The Breccia dolomite body has two clearly differentiated zones; the lower southern area is composed of limestone breccias (Figs $10 \& 11 \mathrm{a}, \mathrm{c}$ ). These breccias are made up of angular limestone clasts cemented by one or more saddle dolomite and calcite isopachous cement phases. The 
Geological Society, London, Special Publications published online September 5, 2012 as doi:

10.1144/SP370.10

E. IRIARTE $E T A L$.
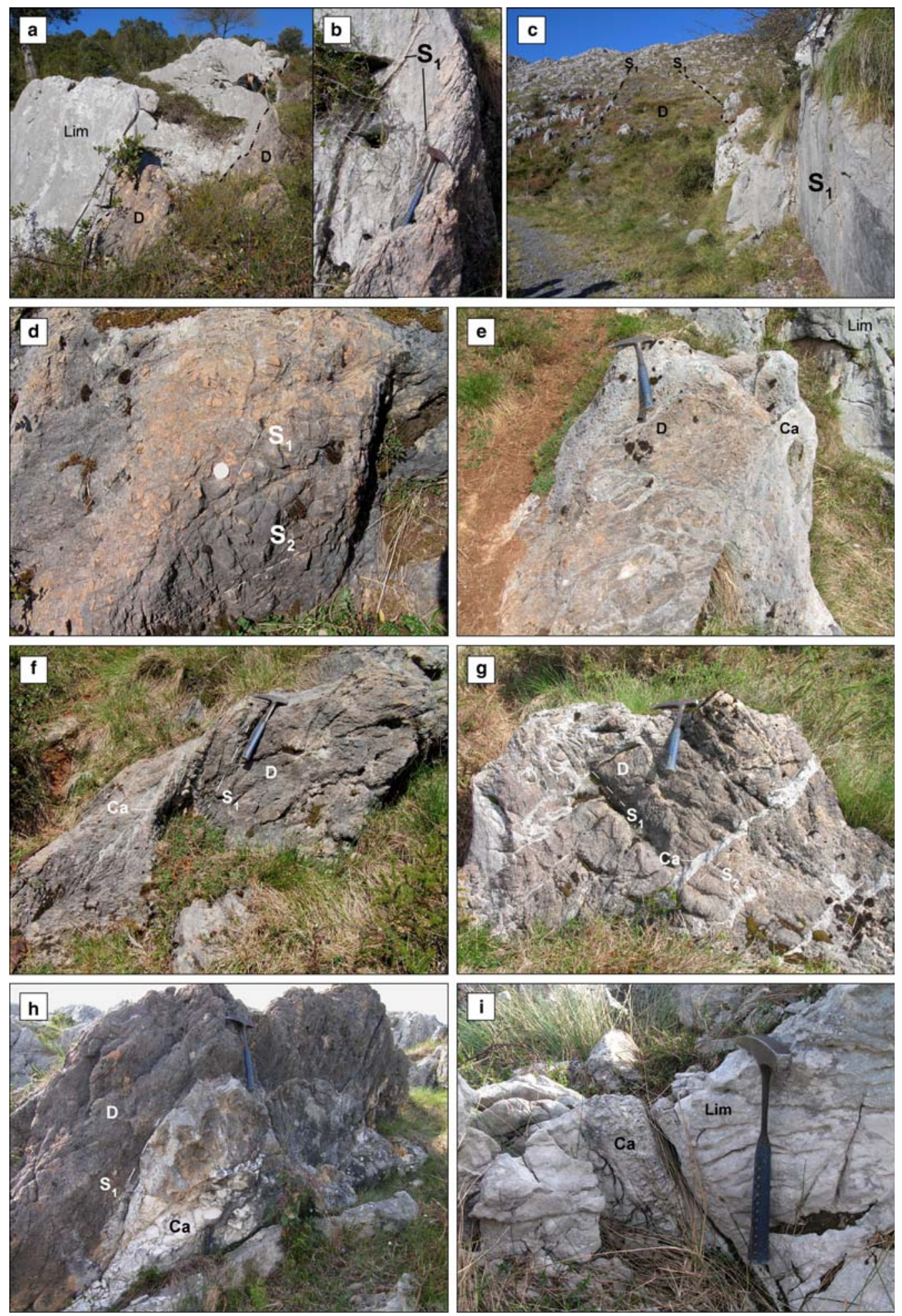

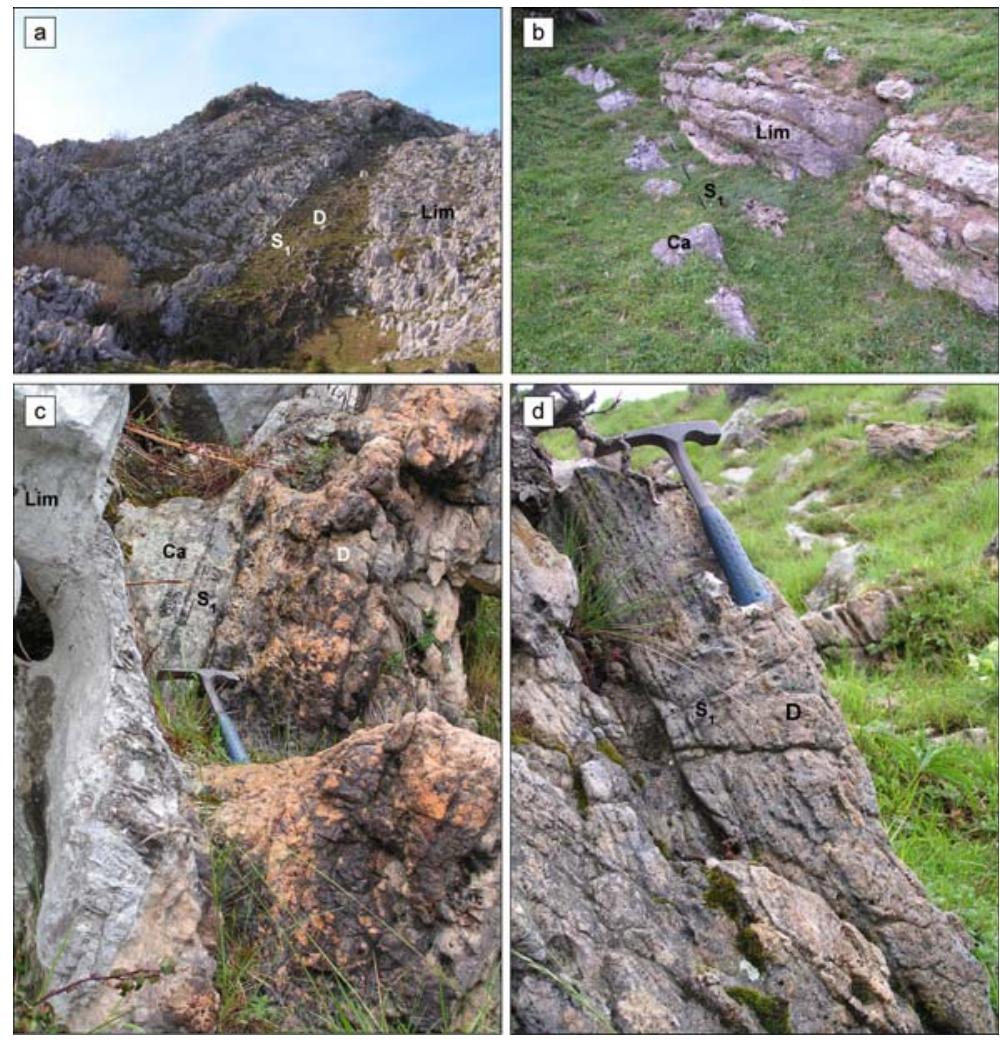

Fig. 8. Ranero East megajoint. (a) View of megajoint in its upper part. (a, b) Calcite vein (left) in the lower end of the megajoint crosscutting basinal calcarenitic and marly sediments. (c) Dolomite/limestone boundary (parallel to $S_{1}$ ). (d) Jointed dolomite with porosity alineation along $S_{1}$ planes forming a 'protozebra' texture. Lim, Limestone;

D, dolomite; Ca, calcite; $S_{1}$ and $S_{2}$, joint set.

limestone clasts vary in size from centimetre to metre scale. A lateral zonation with increasing brecciation and clast rotation is visible laterally from intact host limestone to densely jointed limestone, dolomitecemented limestone crackle float breccia and finally dolomite- and calcite-cemented limestone rubble float breccia (Morrow 1982; Fig. 11a, c).

The upper half of the dolomite body is composed of a large dolomite mass where different dolomite facies and textures are visible (Figs $10 \& 11 \mathrm{~b}$ ). The dolomite facies and textures observed are different from the ones observed in Ranero megajoints.
Sucrosic and saddle dolomite are the main dolomite facies (López-Horgue et al. 2009, 2010). They are arranged in different size zebra bandings (sensu Nielsen et al. 1998; López-Horgue et al. 2009) and heterogeneous vuggy textures (López-Horgue et al. 2010). Large and irregular massive zones of sucrosic and/or saddle dolomite are present too. In general there is not a facies gradation through the dolomite body; the different textures are heterogeneously distributed and densely crosscut by $S_{1}$ and $S_{2}$ joint-sets (Fig. 11d). Dolomites have abundant millimetre- to centimetre-scale vuggy porosity. Calcite is present

Fig. 7. Ranero West megajoint. (a, b) View of dolomite body and the host limestone. The boundary between both is parallel to steeply dipping $S_{1}$, which is densely developed in the host limestone near the dolomite body (b). (c) A neighbouring dolomite body also limited by $S_{1}$ joints. (d) Different joint-sets in dolomite. (e-g) Calcite (Ca, grey) veins intruding dolomite $(\mathrm{D}$, brownish) through joint planes. Locally the dolomite is brecciated and clasts are cemented by calcite (d). $S_{1}$ acts as preferential pathway for calcite mineralization (e-f). (h, i) Calcite veins intruding dolomite $(\mathrm{g})$ and in the upper end of the megajoint $(\mathrm{h})$, suggesting that the last extensional phase provoked the propagation of megajoint tips, fluid flow and calcite precipitation. Lim, Limestone; D, dolomite; Ca, calcite; $S_{1}$ and $S_{2}$, joint set. 
locally in the dolomite/limestone boundary filling extensional $S_{1}$ and $S_{2}$ joints and also partially the vuggy porosity (Fig. 11d).

No fault planes have been observed. The dolomite-filled joint-mesh acted as pathway for the dolomitizing fluids. The mineralization events documented are more abundant than in Ranero megajoints. The heterogeneous arrangement of different dolomite facies and their crosscutting relationships suggest repeated brecciation and mineralization events in the Breccia body. Hydraulic breccia cements show at least three main events of fracturing, fluid-flow and dolomite (two events) and calcite (one event) mineralization (Fig. 11).
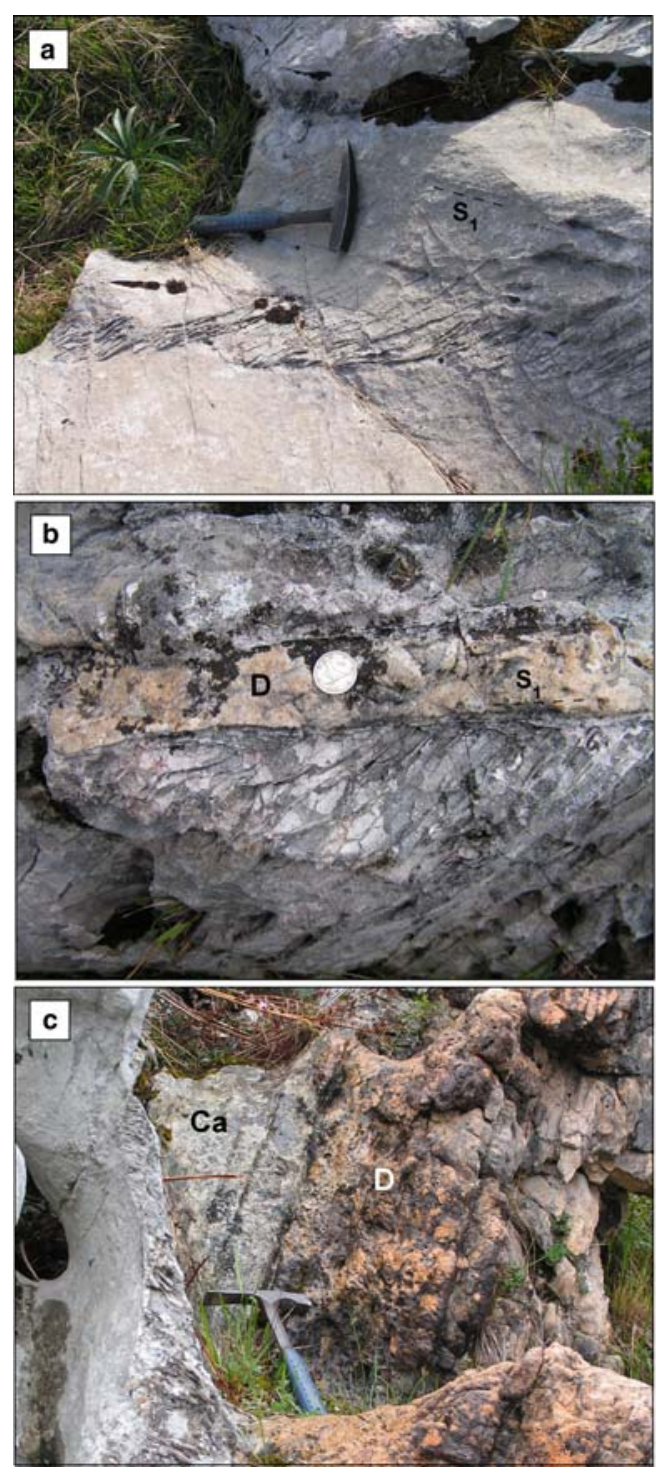

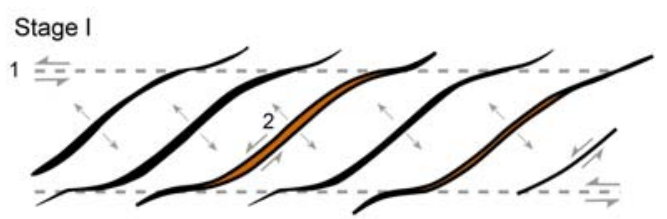

1. Sinistral transtensive stress event affects Ranero limestone. 2. Transtensive en-echelon joints (also $S_{1} \& S_{2}$ ) develop.

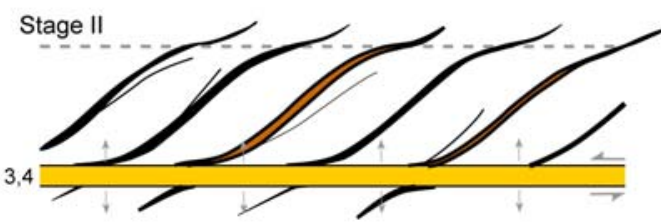

3. Transtensional $\mathrm{S}_{1}$ parallel band formation with increasing displacement.

4. Fracture porosity creation, fluid flow and dolomitization (fine replacive dolomite) in the transtensional band.

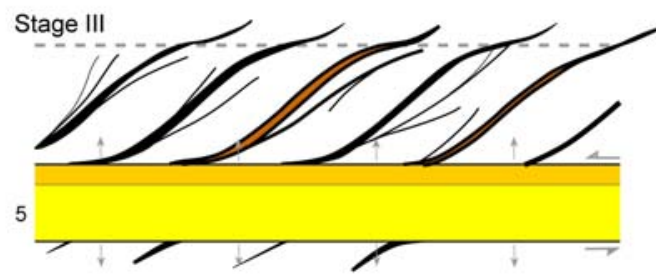

5.Developed transtensional megajoint with higher displcement core (dolomite/calcite mineralized zone) and damage zone of abandoned en-echelon joints.

Fig. 9. Ranero megajoint kinematic indicators and summary of their progressive structural development. (a) Stage I, small-scale dolomite en echelon transtensional joints in limestone, some filled with hydrothermal minerals, coalesce into low displacement $S_{1}$ shear joints (dashed lines). (b) Stage II, branching of en echelon fractures and transtensional cataclasite band formation with increasing fluid flow and mineralization (dolomite and/or calcite). Thin continuous lines calcite/dolomite crystal growth phases in relation to opening and slip events. (c) Stage III, fully developed mineralized zone with a damage zone of abandoned en echelon fractures (modified from Neville 1968 and Petit et al. 1999). 


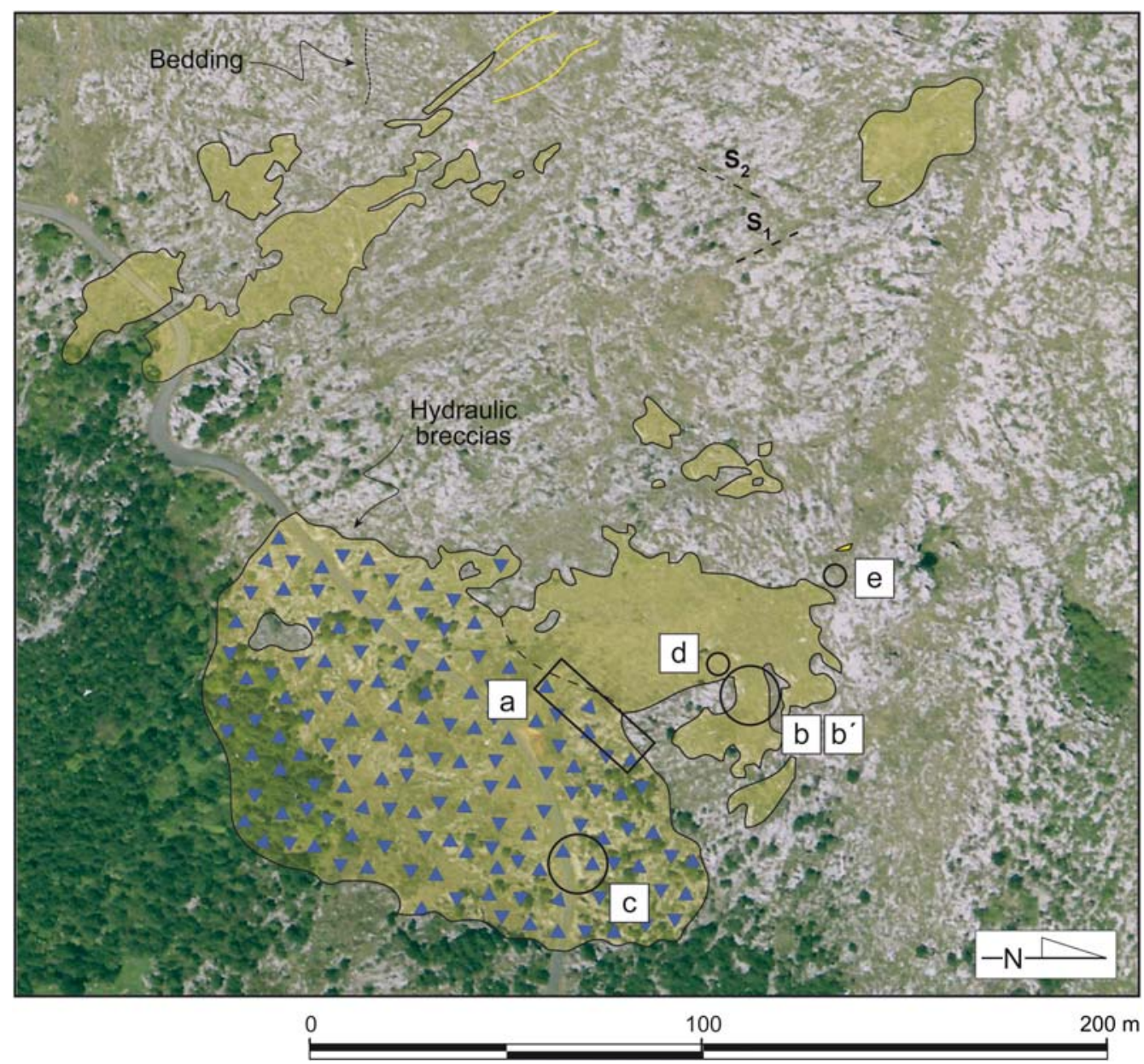

Fig. 10. Aerial photograph and detailed cartography of Breccia dolomite body and location of the photographs shown in Figure 11.

\section{Pozalagua fault dolomite body}

The Pozalagua fault dolomite body is the largest in the Ranero massif area. It extends $5 \mathrm{~km}$ northwards along the Pozalagua fault through inner platform limestones to the junction with the Ramales fault (Figs $2 \& 12$ ). In the Pozalagua Quarry area the dolomite body is $594 \mathrm{~m}$ long in a NW-SE direction and $\pm 230 \mathrm{~m}$ wide. It is vertically elongated and parallel to $S_{1}$ showing laterally branching geometries, especially in its western margin, where the host limestone locally exhibits an intense jointing and breccia facies (Figs 12, 13a \& 14). The east margin of the dolomite body is rectilinear with a number of dolomite/calcite-filled anastomosing fractures and secondary decametre-scale dolomite bodies that diverge from the main dolomite mass.
The upper end pinches out progressively towards the NW. The host limestones are reef-margin and foreslope carbonates characterized by microbial micritic carbonates and bedded micritic-marly limestones, respectively (López-Horgue 2000).

As in the previous Breccia dolomite body, the dolomite facies and textures recognized consist mainly of variable scale (millimetre to metre) zebra and heterogeneous vuggy textures composed of sucrosic and saddle dolomite (Fig. 13; López-Horgue et al. 2010). Locally, fine-grained replacive dolomite has been observed forming millimetre-scale zebra textures in peripheral areas of the dolomite body. These textures are crosscut or assimilated by metre size massive dolomite irregular areas made from saddle or/and sucrosic bodies (Fig. 13c). The dolomite is affected by pervasive jointing $\left(S_{1}\right.$ and $S_{2}$; 

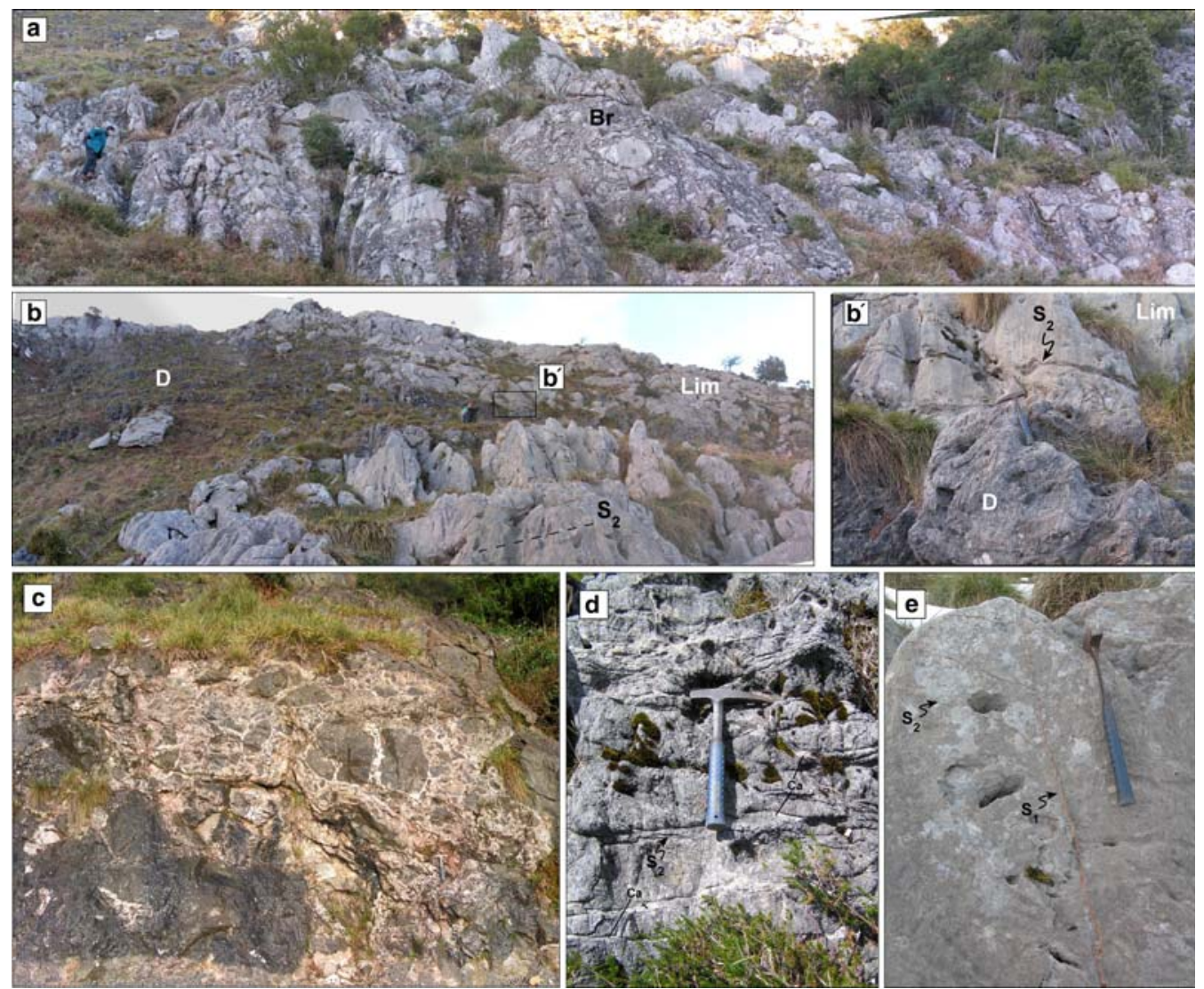

Fig. 11. Breccia dolomite body. (a) Hydraulic breccia zone. (b, $\left.\mathbf{b}^{\prime}\right)$ Lateral branching of the main dolomite body parallel to $S_{2}$ joint-set (view b' detail photograph). (c) Hydraulic limestone breccia cemented by various phases of dolomite cement. (d) Calcite veins intruding dolomite through $S_{2}$ joint-set. (e) Dolomite filled $S_{1}$ and $S_{2}$ joints in the host limestone. Lim, Limestone; D, dolomite; Ca, calcite; $S_{1}$ and $S_{2}$, joint set.

Fig. 14) and brecciation that generate dolomite breccia facies. The host limestone is also affected by joints $\left(S_{1}\right.$ and $\left.S_{2}\right)$ around the dolomite body. The outcrops of the dolomite facies and textures observed in the quarry walls show the heterogeneous distribution of the facies that point to the existence of a repeated brecciation and subsequent mineralization after seismic activity of the Pozalagua fault (Lopéz-Horgue et al. 2011b; Fig. 13c, d).

Macroporosity is abundant ranging from millimetre-scale vugs to decimetre scale caverns. As in the other dolomite bodies described previously, late-stage calcite veins cut across the dolomite body. Some extensional fractures that crosscut the dolomite body and vugs are cemented by large crystals of rhombohedral calcite of hydrothermal and/or telogenetic (low temperature and meteoric fluid derived) origin (López-Horgue et al. 2010; Millán et al. 2011). Several horizontal stylolites with iron oxide remains post-date dolomitization (Fig. 13d). Fault planes and related cataclastic materials are visible in the Pozalagua Quarry outcrops and indicate the existence of a fractured damage zone related to the Pozalagua fault (Fig. 13d).

The complex crosscutting relationships of the dolomitic facies in the walls of the Pozalagua quarry suggest that the Ranero area dolomites represent a complex succession of fracturing and dolomitization events. A late-stage hydrothermal calcite cavity-filling precipitation event post-dates most of the dolomitization pulses (López-Horgue et al. 2010). At least four different phases of brecciation and precipitation could be locally ascertained owing to crosscutting relationships between hydrothermal dolomite and calcite cements, but it is difficult to generalize (López-Horgue et al. 2011b; Swennen et al. 2012). Sinistral transtensive stress 


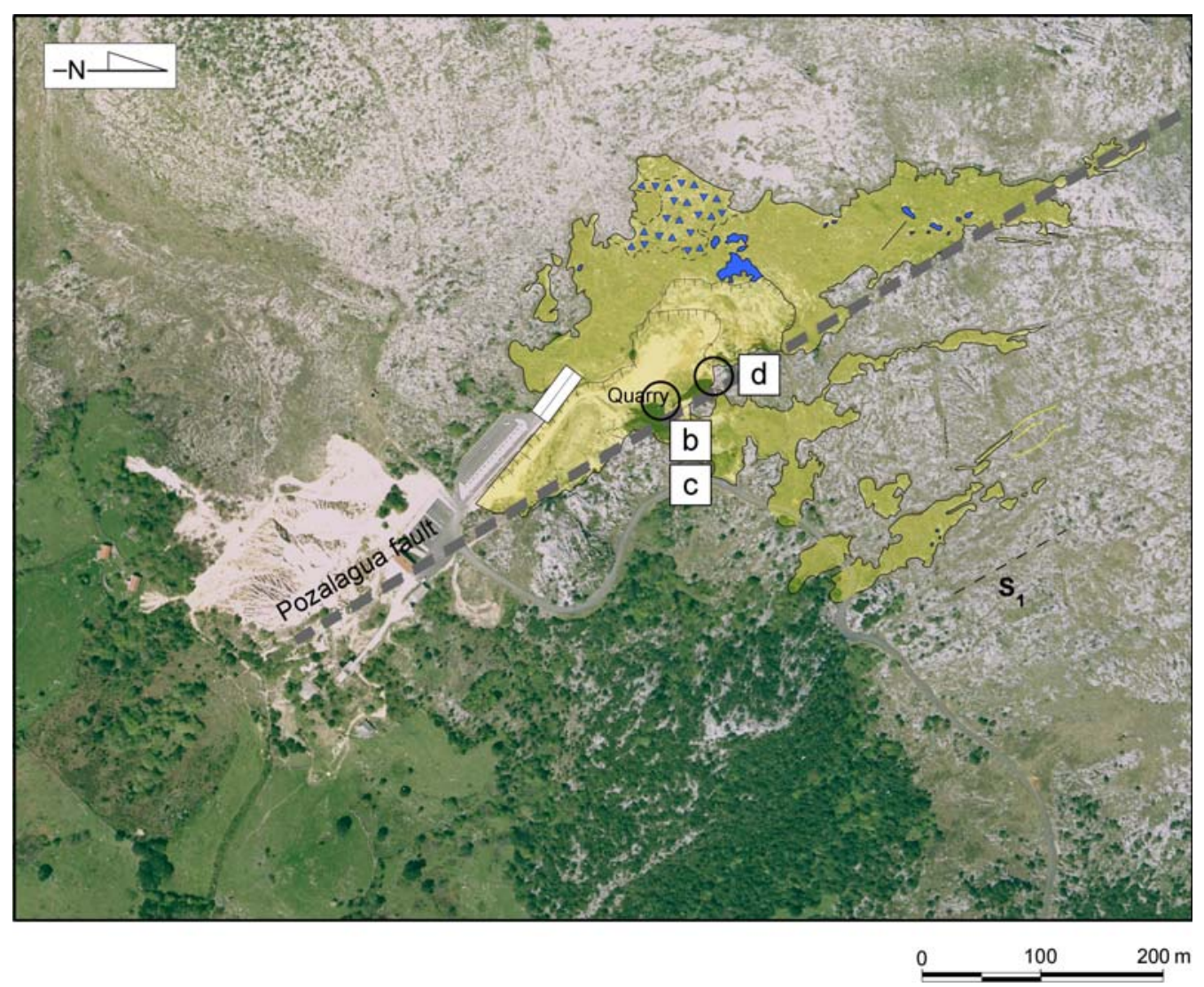

Fig. 12. Aerial photograph and detailed cartography of Pozalagua fault dolomite body and location of the photographs shown in Figure 14.

along the Pozalagua fault zone is inferred from the fracture pattern observed (Fig. 14).

All the features mentioned above and the fact that the highest measured fluid-inclusion temperatures in Asón Valley HTDs are from the dolomites and calcites of the Pozalagua quarry area (75$240^{\circ} \mathrm{C}$, López-Horgue et al. 2010) indicate the existence of an important pathway for dolomitizing fluids along the Pozalagua fault zone. Fluid flow along this structural corridor extended through the fracture mesh to neighbouring areas where other dolomite bodies were also formed.

\section{Interplay between fracturing and fluid-flow: discussion}

From outcrop data it can be inferred that a relationship between dolomite and tectonic fractures existed that acted as conduits for the dolomitizing fluids. These fluids circulated along fractures (fracture porosity) irrespective of the host limestone facies. As proposed in other HTD settings (e.g. Davies 2001; Davies \& Smith 2006), in the Asón Valley HTDs both high-temperature fluids and high fluid pressures are often involved along active faults and fractures, commonly of strike-slip origin (LópezHorgue et al. 2010).

During the middle Cretaceous, a regional-scale fluid throughflow area was formed in the Ranero massif (Velasco et al. 1994; Grandia et al. 2003) owing to the onset of an overlapping stepover between the Cabuérniga and Ruahermosa basement faults. This generated a dilational jog in the overlapped area (López-Horgue et al. 2010). The distribution of dolomite bodies and transtensive structural features is in agreement with the fluidflow model proposed for overlapping stepovers (Connolly \& Cosgrove 1999; Fig. 4c). Sites of probable mineralization coincide with regions of high fluid throughflow and the principal reservoirs predicted are the intra-jog areas such as the Pozalagua fault, Breccia body and Ranero megajoints in the studied area (Fig. 4). Additional fluid accumulation 
Geological Society, London, Special Publications published online September 5, 2012 as doi:

10.1144/SP370.10

E. IRIARTE ET $A L$.
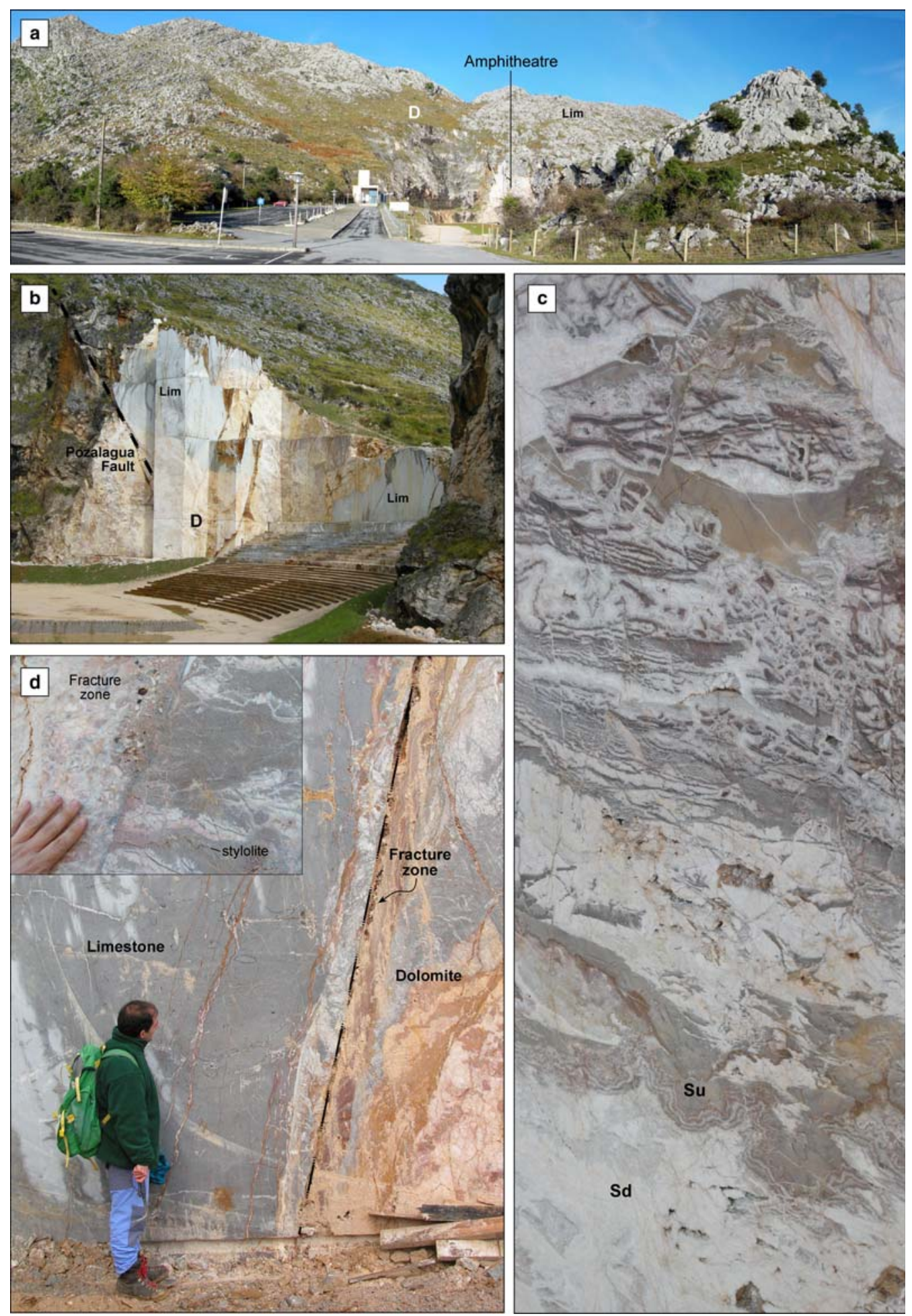


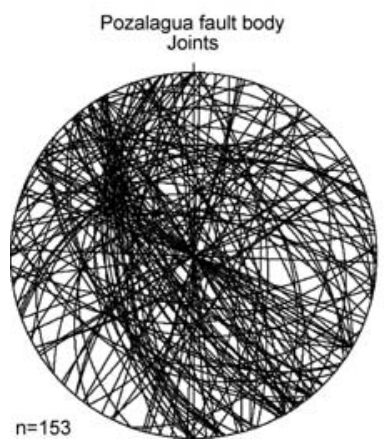

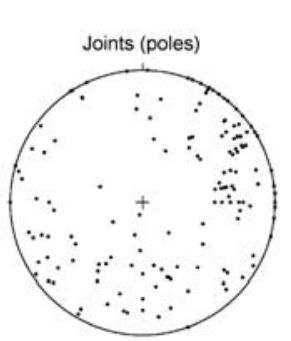

Mean Principal Orientation $=82 / 240$ Mean Resultant direction $=35-256$
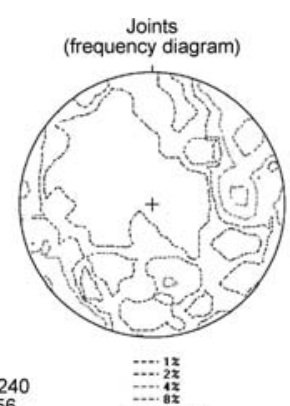

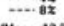

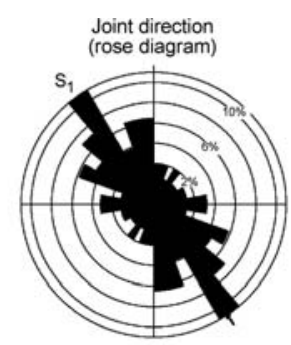

Sector angle $=10^{\circ}$ Scale: tick interval $=2 \%$ [3.1 data] Maximum $=13.0 \%$ [20 data] Mean Resultant dir'n $=146-326$ $\left[95 \%\right.$ Confidence interval $\left.= \pm 21^{\circ}\right]$

Fig. 14. Stereograms and rose diagram of joint measurements in Pozalagua fault dolomite body.

may occur along stepover bounding faults such as the Ruahermosa fault and its important hydrothermal calcite mineralization that also formed during Albian times and in a similar context along the Ramales platform margin $15 \mathrm{~km}$ to the east (Aranburu et al. 2002; Fig. 4).

The formation of the described dolomite bodies is closely related to the fracture-mesh (joints and faults) affecting the Ranero limestones. The features observed could be ascribed to a fault/fracture mesh formed by a combination of shear and extensional fractures (Hill 1977; Sibson 1994; Fig. 15). Such structures probably developed by the breaching of seals to overpressured fluid compartments (Phillips 1972; Sibson 1994). The Pozalagua fault acted as a main pathway for the fluid-flow in the dilational jog and controlled the formation of the main dolomite body in the Ranero stepover. The repeated dolomitization and brecciation processes masked the main fault zone, but some related minor faults bounding small dolomite branches clearly indicate the presence of displacement along their planes with formation of cataclastic fabrics and rocks (Fig. 13d). The Pozalagua fault body dolomites show a multiphase fracturing/dolomitization process related to tectonic movements of the Pozalagua fault (Lopéz-Horgue et al. 2011b). These multiple tectonic events led to the breaching of seals to overpressured fluid compartments and the ascent of hot overpressured mineralizing fluids from basinal deep source areas to the south (Karrantza

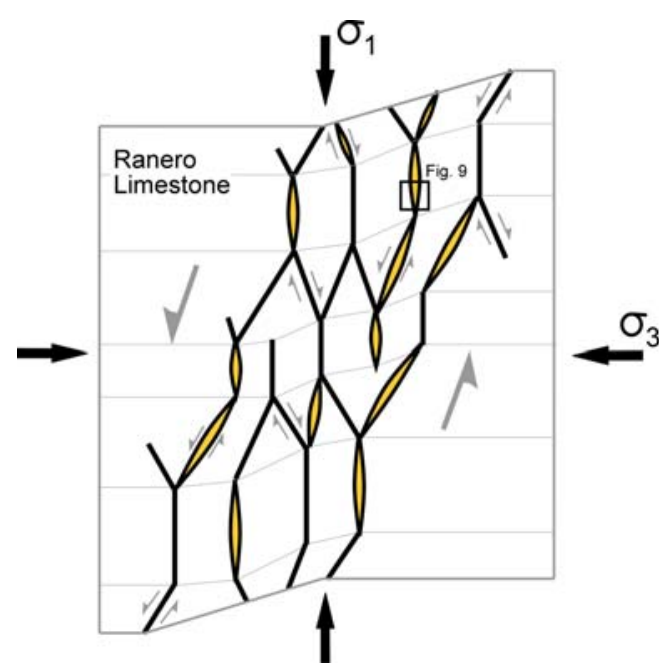

Fig. 15. Hill fault/fracture meshes acting as fluid conduits within a transtensional stress regime, as transtensional chimmneys or fuzzy normal faults. Ranero megajoints are interpreted as major fractures formed owing to the coalescence of many fractures of the mesh. Figure 9 represents one of the mechanisms proposed for the fracture formation in the mesh involving transtensional stress and fluid flow. Note that the passage of large fluid volumes would lead to increase disorganization and brecciation within the fault/fracture mesh, as seen in the Breccia body (modified from Sibson 1994).

Fig. 13. Pozalagua fault dolomite body. (a) Panoramic view of Pozalagua Quarry and Amphitheatre (northeastwards). (b) Panoramic view of Pozalagua Amphitheatre (northeastward) where lateral branching of the dolomite body be present in the walls. (c) Dolomite facies from Pozalagua Quarry wall. Dolomite facies are mainly composed of saddle (Sd, white) and sucrosic dolomite (Su, dark). Note zebra lamination and fractured dolomite areas. The represented area is $2 \mathrm{~m}$ high. (d) Secondary fracture related to the main Pozalagua fault. The fault zone is decimetre-scale wide and has cataclastic dolomite breccias and minor fractures associated (view detail photograph with indication of horizontal stylolites post-dating dolomites). 

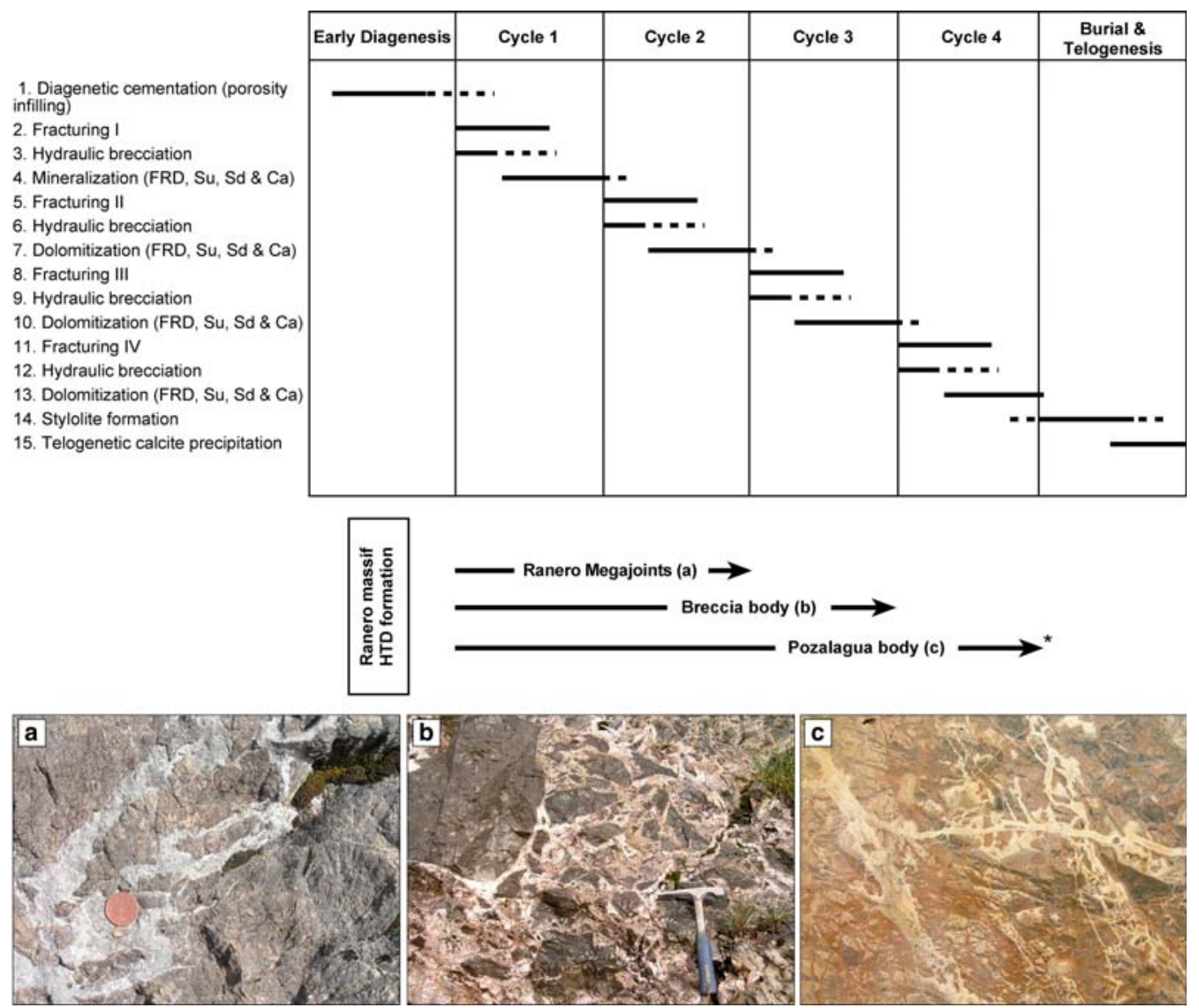

Fig. 16. Simplified paragenetic sequences of the dolomite bodies in Ranero massif. Dolomite bodies (a, Ranero West megajoint; b, breccia body; and c, Pozalagua fault body) reflect different mineralization cycles composed of fracturing and mineralization events. The cycle number and textural heterogeneity increases towards Pozalagua fault body. * Pozalagua fault body reflects a minimum of four well-developed fracturing/mineralization cycles; more cycles could be locally inferred, but their correlation by crosscuting relationship is difficult.

Basin; Lopéz-Horgue et al. 2010). These were responsible of multiple phases of dolomitization (fault-valve action of Sibson 1990, 1994; Figs 15 \& 16).

As a consequence of the extensional (transtensional) stress-field in the Ranero area, the brittle Ranero limestone was densely fractured by a fault/fracture mesh formed by $S_{1}$ and $S_{2}$ joint-sets (Figs $15 \&$ 17) during many tectonic pulses. Overpressured fluids ascending through main pathways would force the widening and coalescence of the fractures and easily migrate laterally through the fracture mesh. The fluid circulated and concentrated preferentially in more fractured areas with increased permeability (extensional chimneys and fuzzy normal faults of Sibson 1994) creating dolomite bodies also out of the main fluid-flow pathway (Figs 9, 15 \& 17). The Breccia and Ranero megajoint dolomite bodies correspond to this type of peripheral body. The Pozalagua body and especially the Breccia dolomite body (very close to the Pozalagua fault) exhibit hydraulic breccias normally related to the passage of large overpressured fluid volumes through a fault/fracture mesh enhancing the fracture-porosity (Phillips 1972; Sibson 1994). In this process, the rock fragments were initially bounded by transtensional shear fractures forming a mesh (Fig. 9) that acted as fluid conduits within an extensional stress regime, forming extensional chimneys (sensu Sibson 1994; Fig. 15). The passage of large fluid volumes led to an increased disorganization and brecciation within the fracture mesh forming the hydraulic breccia (cf. Sibson 1992, 1994) and caused rotation and progressive comminution of the breccia fragments (Redwine 1981; Sibson 1994). 


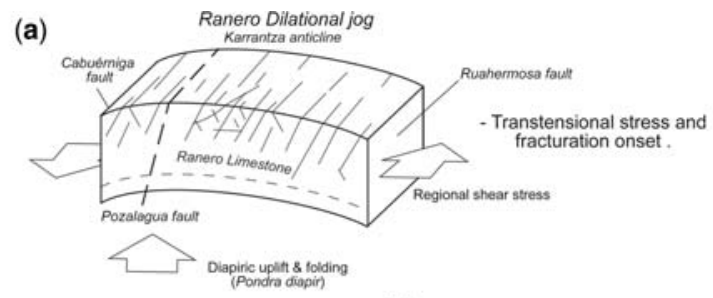

(b)

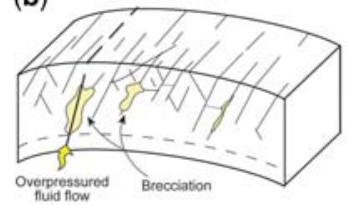

(c)

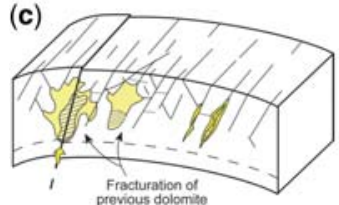

(d)

- Transtensional fracturation of estone and fluid-flow cycle - Dolomitization Event I. Hydrothermal precipitation
self-sealing process. (d)

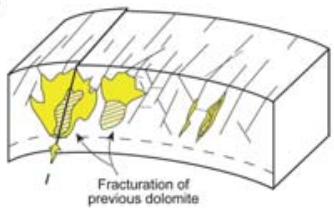

(e)

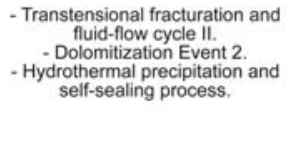

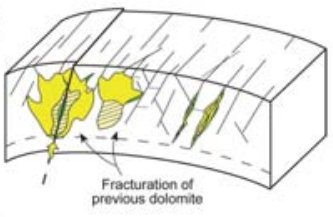

:Main areas of calcile precipitation during all the cycles.
- Transtensional fracturation and fluid-flow cycle III. - Hydrothermal precipitation and self-sealing process.

Fig. 17. Schematic genetic model for Ranero massif HTD. A multiphase generation of dolomite bodies is proposed. Repeated regional tectonic transtensional events triggered permeability enhancement (fracture porosity), overpressured fluid-flow, dolomitization of the host limestone and permeability self-sealing by hydrothermal precipitation of dolomite/calcite. Green colour areas show main areas of calcite precipitation during the different mineralization cycles.

The vertical transition from a lower (southern) hydraulic limestone breccia cemented by dolomite to a massive dolostone in the upper part of the Breccia dolomite body probably reflects a rapid drop in the fluid pressure (Figs $10 \& 11$ ). This rapid fluid pressure drop probably resulted from an abrupt drop in confining stress as a consequence of the breaching of the seal (the Ranero limestone) owing to tectonic events (Phillips 1972; Sibson 1992). A lower pressure gradient resulted in a possible desgassing and lowering of the fluid flow velocity and/or temperature in the upper part of the Breccia body. These changes could have lea to a higher fluid-rock interaction and the formation of extensive replacive dolomite and calcite precipitation affecting the host limestone (Phillips 1972; Holland \& Malinin 1979; Zheng 1990).

The Ranero megajoints reflect more peripheral fluid circulation, probably less intense than in the Pozalagua and Breccia bodies. It is likely that they were active only during two, perhaps more overpressured, fluid-flow events (Fig. 16). Fluid circulation and dolomitization mainly occurred through $S_{1}$ transtensional joints, spreading vertically (Fig. 9). The calcite veins denote a last-stage hydrothermal fluid (López-Horgue et al. 2010; Millán et al. 2011) that intruded the dolomite body through extensional joints (preferentially $S_{1}$ ) and also formed hydraulic breccias post-dating previous fracturingdolomitization events (Figs 7 \& 8). Both Ranero dolomite megajoints reflect two main fracturing, fluid-flow and mineralization events. Fluid-flow events are separated by a fracturation event and are recognized by different mineralization products (dolomite and calcite) and their textural crosscutting relationship: intrusion and hydraulic brecciation. The studied joint types and their arrangement within the megajoints and the host limestone (Fig. 9) suggest the presence of sinistral transtension during the formation of extensional joint-sets that channellized the mineralizing fluid-flow.

A gradation in dolomite facies and textures is visible from the main Pozalagua fault body to the Ranero megajoints (Fig. 16). In the Pozalagua quarry more heterogeneous and pervasively replacive and cementing polyphasic dolomitization, with a minimum of four fracturing-mineralization cycles, is observed (Lopéz-Horgue et al. 2010; Kurz et al. 2011; Swennen et al. 2012). In the Ranero megajoints, homogeneous dolomite facies and replacive but not pervasive dolomitization reflect only two fracturing-mineralization cycles. These differences could reflect a proximal-distal trend from the main fluid-flow area along the Pozalagua fault to the Ranero megajoints. This gradation is visible also in the jointing pattern of both the host 
limestone and dolomite bodies, and it is more dense and with better developed joint-sets around and in the Pozalagua body $\left(S_{1}\right.$ and $\left.S_{2}\right)$ than in the Ranero bodies area, where $S_{1}$ is the most conspicuous joint-set (Fig. 4).

The Ranero megajoints could be referred to either as subvertical extensional chimmneys or as fuzzy normal faults with an overall component of shear across the mesh (Sibson 1994). Fluid overpressure and repeated onset of transtensive stress pulses with subsequent mineralization events (i.e. the 'Crack-seal, slip' mechanism of Petit et al. 1999) progressively connected and enhanced the fracture mesh, forming hectometre-scale Ranero megajoints (Figs 9, 15 \& 17).

In extensional settings, the main joint-set $\left(S_{1}\right.$ in Ranero massif) is always developed perpendicular to the main extensional stress direction so it could be inferred that the extension was NE-SW directed during the dolomitization in the Ranero massif area (Figs 4 \& 18). However, that stress direction is not in accordance with the measured and theoretical stress orientation for Ranero stepover in a sinistral strike-slip regime of Cabuerniga and Ruahermosa faults (Figs 4b \& 18; García-Mondéjar et al. 1996; Aranburu 1998: López-Horgue 2000). Structural data from measured joint-sets indicate the extensional (transtensional) NE-SW direction instead of a compressive (transpressive) stress (Fig. 4). This can be explained by the formation of a wide-scale ESE plunging Karrantza anticline at the junction of Cabuerniga and Ramales faults that affected the Ranero stepover area during the dolomitization process (Figs 4, $17 \& 18$ ). Based on sedimentological and stratigraphical features (e.g. angular unconformities affecting the Ramales platform margin in Ranero massif area), López-Horgue (2000) suggested the formation of the Karrantza anticline as early as the Albian. Its formation was related to the intrusion of the Pondra diapir (Fig. 4), composed of Triassic Keuper claystones, evaporites and dolerite bodies, through the transtensive Cabuerniga basement fault (wall-type diapirism). The diapiric material was also suggested as the most probable origin for the magnesium of the hydrothermal fluids involved in the dolomitization process (leaching of claystones, evaporites and diorites; Grandia et al. 2003; López-Horgue et al. 2010). The Ranero massif corresponds to the NE limb of the Karrantza anticline, and the fracture mesh measured in the area would correspond to the local transtensional stress created owing to the addition of the extensional stress related to the diapiric folding and the regional transtensive stress affecting the dilational jog (Figs $17 \& 18$ ).

\section{Conclusions}

An overlapping stepover area between two major basement faults in the western margin on the Basque Cantabrian Basin, the Cabuerniga and Ruahermosa transtensional faults was the scenario for different scales and types of extensional fractures (joints and faults) and folds (Karrantza diapiric anticline) affecting the Albian Ranero limestones. These fractures were formed in a dilational jog, a regional fluid throughflow area that acted as the main pathway for overpressurized dolomitizing fluids and diapiric materials (Pondra diapir), so that they are proposed to explain the dolomite bodies in the Ranero massif area.
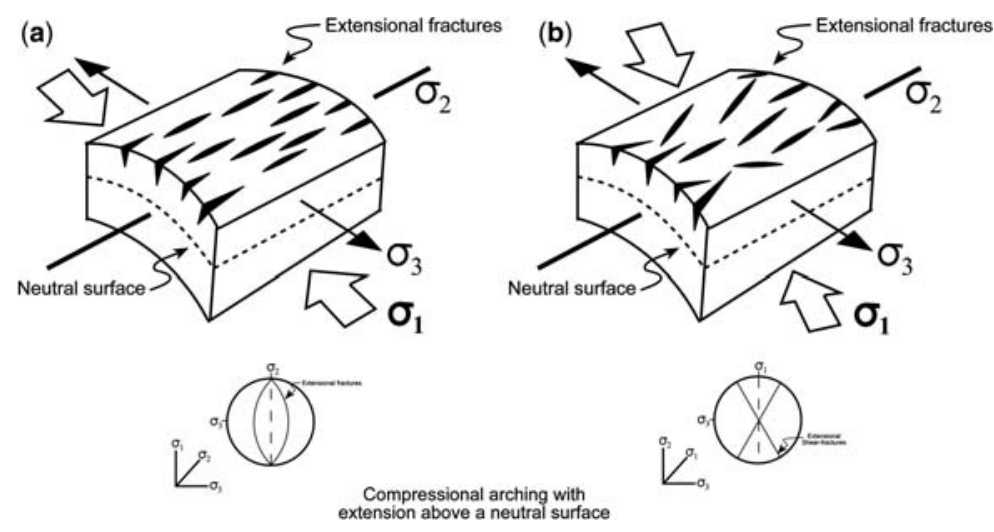

Fig. 18. Master joint orientations related to principal stress axes in an anticline. (a) Joints at the crest of a major anticline with orientation of normal faults. (b) Shear joints at the crest of a major anticline with acute angle made by the joints intersected with the axial line (modified from Hatcher 1995 after Wise et al. 1985 and Neville 1968). The second model, with an oblique stress component and coetaneous anticlinal folding (Karrantza anticline) fits the measured joint-sets $\left(S_{1}\right.$ and $S_{2}$ ) in Ranero massif area. 
Confined fluid pressure and the additional regional transtensive stress regime interacted to influence the fluid flow, hydraulic fracturing and formation of HTD bodies. Fluid movement along active faults and extensive chimneys is considered cyclic and related to repeated transtensive tectonic events. These events formed regional to local tectonic structures (folds and fractures) that created and enhanced fracture porosity (joint and fracture mesh), promoting overpressured fluid migration, dolomite mineralization and subsequent drops in confining pressure (cf. fault-valve mechanism of Sibson 1992). The migration of overpressured fluids leads to hydraulic brecciation and dolomite and calcite precipitation. The eventual occlusion of the fracture porosity by cementation produced the self-sealing of the system at the end of each mineralization cycle and the beginning of a new overpressuring phase owing to tectonic stress accumulation.

Both the recognition of synchronous structural processes, features developed during fluid flow channelling and mineralization processes, and the understanding of the role of fluid pressure in fracture porosity enhancement during successive tectonic phases, are paramount to understanding the Ranero area HTD formation process.

This work was funded by Total and the University of the Basque Country research project EHU09/11. We thank GSL editor J. Garland and C. Taberner (Shell GSNL) and an anonymous reviewer for detailed reviews and suggestions that improved the original manuscript.

\section{References}

AL-Aasm, I. 2003. Origin and characterization of hydrothermal dolomite in the Western Canada Sedimentary Basin. Journal of Geochemical Exploration, 78-79, $9-15$.

Aranburu, A. 1998. El Aptiense-Albiense de TrucíosGüeñes (Oeste de Bizkaia). Unpublished $\mathrm{PhD}$ thesis, Universidad del País Vasco/Euskal Herriko Unibertsitatea.

Aranburu, A., Fernandez-Mendiola, P. A., LópezHorgue, M. A. \& García-MondéJar, J. 2002. Syntectonic hydrothermal calcite in a faulted carbonate platform margin (Albian of Jorrios, northern Spain). Sedimentology, 49, 875-885.

AYDIN, A. 2000. Fractures, faults, and hydrocarbon entrapment, migration and flow. Marine and Petroleum Geology, 17, 797-814.

Aydin, A. \& Nur, A. 1985. The types and role of stepovers in strike-slip tectonics. In: BIDDLE, K. T. \& ChristieBLICK, N. (eds) Strike-Slip Deformation, Basin Formation, and Sedimentation. SEPM, Tulsa, OK, Special Publications, 37, 35-44.

Cantrell, D. L., Swart, P. K., Handford, R. C., Kendall, C. G. \& Westphal, H. 2001. Geology and production significance of dolomite, Arab-D reservoir, Ghawar field, Saudi Arabia. GeoArabia, 6, 45-60.

Connolly, P. T. \& Cosgrove, J. W. 1999. Prediction of static and dynamic fluid pathways within and around dilational jogs. In: MCCAFFrEY, K. J. W., LONERGAN, L. \& WiLkinson, J. J. (eds) Fractures, Fluid Flow and Mineralization. Geological Society, London, Special Publications, 155, 105-121.

Cosgrove, J. W. 1995. The expression of hydraulic fracturing in rocks and sediments. In: AMEEN, M. S. (ed.) Fractography: Fracture Topography as a Tool in Fracture Mechanics and Stress Analysis. Geological Society, London, Special Publications, 92, 187-196.

Cosgrove, J. W. 1998. The role of structural geology in reservoir characterization. In: CowARD, M. P., DALTABAN, T. S. \& Johnson, H. (eds) Structural Geology in Reservoir Characterization. Geological society, London, Special Publications, 127, 1-13.

Coward, M. P., Daltaban, T. S. \& Johnson, H. (eds) 1998. Structural Geology in Reservoir Characterization. Geological Society, London, Special Publications, 127.

Davies, G. R. 2001. Hydrothermal (Thermobaric) Dolomite Reservoir Facies. Proprietary Report, GDGC, Calgary.

DAvies, G. R. \& Smith, L. B. JR. 2006. Structurally controlled hydrothermal dolomite reservoir facies: an overview. AAPG Bulletin, 90, 1641-1690.

García-MondéJar, J., Agirrezabala, L. M. et aL. 1996. Aptian-Albian tectonic pattern of the BasqueCantabrian Basin (northern Spain). Geological Journal, 31, 13-45.

García-MondéJar, J., Fernández-Mendiola, P. A. ET AL. 2004a. El Aptiense-Albiense de la Cuenca VascoCantábrica. In: VerA, J. A. (ed.) Geología de España. SGE-IGME, Madrid, 291-296.

García-MondéJar, J., Fernández-Mendiola, P. A. ET AL. 2004b. Extensión del Aptiense-Albiense en la Cuenca Vasco-Cantábrica. In: VerA, J. A. (ed.) Geología de España. SGE-IGME, Madrid, 340-343.

García-MondéJar, J., López-Horgue, M. A., AraNBUru, A. \& FernándeZ-Mendiola, P. A. 2005. Pulsating subsidence during a rift episode: stratigraphic and tectonic consequences (Aptian-Albian, northern Spain). Terra Nova, 17, 517-525.

GASPARRINI, M., BAKKER, R. J., BECHSTÄDT, T. \& BONI, M. 2003. Hot dolomites in a Variscan foreland belt hydrothermal flow in the Cantabrian Zone (NW Spain). Journal of Geochemical Exploration, 78-79, 501-507.

Graham, B. R., Girbacea, R., Mesonjesi, A. \& Aydin, A. 2006. Evolution of fracture and fault-controlled fluid pathways in carbonates of the Albanides foldthrust belt. AAPG Bulletin, 90, 1227-1249.

Grandia, F., Canals, A., Cardellach, E., Banks, D. A. \& Perona, J. 2003. Origin of ore-forming brines in sediment-hosted $\mathrm{Zn}-\mathrm{Pb}$ deposits of the BasqueCantabrian Basin, Northern Spain. Economic Geology, 98, 1397-1411.

HAtcher, R. D. 1995. Structural Geology: Principles, Concepts and Problems. 2nd edn. Prentince-Hall, Englewood Cliffs, NJ.

HILL, D. P. 1977. A model for earthquake swarms. Journal of Geophysical Research, 82, 1347-1352. 
Holland, H. D. \& Malinin, S. D. 1979. The solubility and occurrence of non-ore minerals. In: BARNES, H. L. (ed.) Geochemistry of Hydrothermal Ore Deposits. 2nd edn. John Wiley \& Sons, New York, 461-508.

Iriarte, E., López-Horgue, M. A., Schroeder, S. \& CALINe, B. 2011. Interplay between hydrothermal fluid-flow and fracturation in the Asón dolomites (Basque-Cantabrian Basin, Northern Spain). In: Abstract book of communications to the 28th IAS Meeting. Zaragoza, Spain, 567.

Kurz, T., Dewit, J., Buckley, S., Thurmond, J., Hunt, D. \& SWENNEN, R. 2011. Hyperspectral image analysis of different carbonate lithologies (limestone, karst, hydrothermal dolomites): the Pozalagua Quarry case study (Cantabria, NW Spain). Sedimentology, 59, 623-645, doi: http://dx.doi.org/10.1111/j.1365-3091. 2011.01269

Lapponi, F., Casini, G., Sharp, I., Blendinger, W., FerNÁndez, N., Romaire, I. \& Hunt, D. 2011. From outcrop to 3D modelling: a case study of a dolomitized carbonate reservoir, Zagros Mountains, Iran. Petroleum Geoscience, 17, 283-307.

Lonnee, \& Machel, H. G. 2006. Pervasive dolomitization with subsequent hydrothermal alteration in the Clarke Lake gas field, Middle Devonian Slave Point Formation, British Columbia, Canada. AAPG Bulletin, 90, 1739-1761.

López-Horgue, M. A. 2000. El Aptiense-Albiense de Karrantza y Lanestosa (Bizkaia y Cantabria). Unpublished $\mathrm{PhD}$ thesis, Universidad del País Vasco/Euskal Herriko Unibertsitatea.

López-Horgue, M. A., Fernández-Mendiola, P. A. et $A L .2005$. Fault-related hydrothermal dolomite bodies in early Cretaceous platform carbonates, Karrantza area (North Spain): outcrop analogs for dolomite reservoir characterization. In: 10éme Congrès Français de Sédimentologie, Presq'île de Giens, France.

López-Horgue, M. A., Iriarte, E., Schroeder, S., Fernández-Mendiola, P. A. \& Caline, B. 2009. An example on the tectonic origin of zebra dolomites: the San Martín beach outcrop (Santoña, North Spain). Geogaceta, 47, 85-88.

López-Horgue, M. A., Iriarte, E. ET AL. 2010. Structurally controlled hydrothermal dolomites in Albian carbonates of the Asón Valley, Basque Cantabrian Basin, Northern Spain. Marine and Petroleum Geology, 27, 1069-1092.

López-Horgue, M. A., Iriarte, E. \& Caline, B. 2011 a. Structurally controlled hydrothermal dolomitisation in the Albian of the Ramales Carbonate Platform (Basque-Cantabrian Basin, North Spain). In: Arenas, C., Pomar, L. \& Colombo, F. (eds) PreMeeting Field Trips Guidebook. 28th IAS Meeting, Zaragoza. Sociedad Geológica de España, Geoguías, Zaragoza, 7, 65-100.

López-Horgue, M. A., Iriarte, E., Schroeder, S., Caline, B., Aranburu, A. \& García-Garmilla, F. $2011 b$. Seismic cycles of fracturing and hydrothermal dolomitisation in the mid Cretaceous of the Ranero area (Asón HTDs, Basque Cantabrian Basin, Northern Spain). Abstract Book of Communications to the 28th IAS Meeting. Zaragoza, 570.

Millán, M. I., Bernasconi, S. M., López-Horgue, M. A., Iriarte, E. \& Weissert, H. 2011. Clumped isotope analysis of Pozalagua hydrothermal dolomite system (N Spain). Abstract Volume 9th Swiss Geoscience Meeting, Zurich, 143.

Morrow, D. W. 1982. Descriptive field classification of sedimentary and diagenetic breccia fabrics in carbonate rocks. Bulletin of Canadian Petroleum Geology, 30, 227-229.

Nader, F., Swennen, R. \& Ellam, R. 2007. Field geometry, petrography and geochemistry of a dolomitization front (Late Jurassic, central Lebanon). Sedimentology, 54, 1093-1120.

Neville, J. P. 1968. Fault and Joint Development in Brittle and Semibrittle Rock. Pergaon Press, Oxford.

Nielsen, P., Swennen, R., Muchez, P. H. \& Keppens, E. 1998. Origin of zebra dolomites from the Diantian south of the Brabant-Wales Massif, Belgium. Sedimentology, 45, 727-743.

Olivet, J. L. 1996. La cinématique de la Plaque Ibérique. Bulletin des Centres de Recherches ExplorationProduction Elf Aquitaine, 20, 131-195.

Petit, J. P., Wibberley, C. A. J. \& Ruiz, G. 1999. 'Crackseal', slip: a new fault valve mechanism? Journal of Structural Geology, 199, 1199-1207.

PHILliPs, W. J. 1972. Hydraulic fracturing and mineralization. Journal of the Geological Society, London, 128, 337-359.

REDWINE, L. 1981. Hypothesis combining dilation, natural hydraulic fracturing, and dolomitization to explain petroleum reservoirs in Monterey Shale, Santa Maria area, California. In: Garrison, R. E., Douglas, R. G., PISCiatto, K. E., IsaAcs, C. M. \& Ingle, J. C. (eds) The Monterey Formation and Related Siliceous Rocks of California. Society of Economic Paleontologists and Mineralogists, Tulsa, OK, Special Publications, $221-248$.

Ronchi, P., Masetti, D., Tassan, S. \& Camocino, D. 2012. Hydrothermal dolomitization in platform and basin carbonate successions during thrusting: a hydrocarbon reservoir analogue (Mesozoic of Venetian Southern Alps, Italy). Marine and Petroleum Geology, 29, 68-89.

SCHRÖDER, S., RIGAUd, S. ET AL. 2008. Characterization of fault-related dolomites bodies from outcrop analogs: application to carbonate reservoirs. 8th Middle East Geoscience Conference and Exhibition. Bahrain. Conference Program, CD Format.

Shah, M. M., Nader, F. H., Dewit, J., Swennen, R. \& GARCÍA, D. 2010. Fault-related hydrothermal dolomites in Cretaceous carbonates (Cantabria, northern Spain): results of petrographic, geochemical and petrophysical studies. Le Bulletin de la Société géologique de France, 181, 391-407.

Sharp, I., Gillespie, P. ET AL. 2010. Stratigraphic architecture and Fracture Controlled Dolomitisation of the Upper Khami and Bangestan Groups (Cretaceous), Zagros Mountains, Iran - an outcrop case study. In: VAN Buchem, F., Gerdes, K. \& Esteban, M. (eds) Mesozoic and Cenozoic Carbonate Systems of the Mediterranean and the Middle East - Stratigraphic and Diagenetic Reference Models. Geological Sociey, London, Special Publications, 329, 343-396.

Sibley, D. F. \& GregG, J. M. 1987. Classification of dolomite rock textures. Journal of Sedimentary Petrology, 57, 957-965. 
SiBSON, R. H. 1990. Conditions for fault-valve behaviour. In: KNIPE, R. J. \& RutTer, E. H. (eds) Deformation Mechasnism, Rheology and Tectonics. Geological Society, London, Special Publications, 54, 15-28.

Sibson, H. G. 1992. Implications of fault-valve behaviour for rupture nucleation and recurrence. Tectonophysics, 211, 283-293.

Sibson, H. G. 1994. Crustal stress, faulting and fluid flow. In: PARnell, J. (ed.) Geofluids: Origin, Migration and Evolution of Fluids in Sedimentary Basins. Geological Sociey, London, Special Publications, 78, 69-84.

Sibson, R. H., Moore, J. M. C. A. \& Rankin, A. H. 1975. Seismic pumping - a hydrothermal fluid transport mechanism. Journal of Geological Society, London, 131, 653-659.

Sibson, R. H., Robert, F. \& Poulsen, K. H. 1988. High angle reverse faults, fluid pressure cycling and mesothermal gold-quartz deposits. Geology, 16, 551-555.

Simón, S., Canals, A., Grandí́a, F. \& Cardellach, E. 1999. Estudio isotópico y de inclusiones fluidas en depósitos de calcita y dolomita del sector oeste del Anticlinal de Bilbao y su relación con las mineralizaciones de $\mathrm{Fe}-\mathrm{Zn}-\mathrm{Pb}$. Boletín de la Sociedad Española de Mineralogía, 22, 55-71.

SMITH, L. B. 2006. Origin and reservoir characteristics if Upper Ordovician Trenton-Black River hydrothermal dolomite reservoirs in Mew York. AAPG Bulletin, 90, $1691-1718$.
SRIVASTAVA, S. P. 1990. Iberian plate kinematics: a jumping plate boundary between Eurasia and Africa. Nature, 344, 756-759.

Sudrie, M., Caline, B., López-Horgue, M. A., Fernández-Mendiola, P. A. \& Iriarte, E. 2006. Fault-related hydrothermal dolomites in Cretaceous platform carbonates from the Karrantza area (North Spain): outcrop analog for dolomite reservoir characterization. 7th Middle East Geoscience Conference and Exhibition. Bahrain. Conference Program, CD Format.

Swennen, R., Dewit, J. ET AL. 2012. Multiple dolomitisation events along the Pozalagua Fault (Pozalagua Quarry, Basque-Cantabrian Basin, Northern Spain. Sedimentology, 59, 1345-1374.

Velasco, F., Herrero, J. M., Gil, P. P., Álvarez, L. \& Yusta, I. 1994. Missisippi Valley-type, Sedex, and iron deposits in Lower Cretaceous rocks of the Basque-Cantabrian basin, Northern Spain. Society for Geology Applied to Mineral Deposits Special Publication, 10, 247-270.

Wise, D. U., Funicello, R., Parotto, M. \& Salvini, F. 1985. Topographic lineament swarms: clues to their origin from domain análisis of Italy. Geological Society of American Bulletin, 96, 952-967.

ZHENG, Y.-F. 1990. Carbon-oxygen isotopic covariation in hydrothermal calcite during desgassing of $\mathrm{CO}_{2}$. Mineralium Deposita, 25, 246-250. 